\title{
Metabolism in a deep hypertrophic aquatic ecosystem with high water-level fluctuations: A decade of records confirms sustained net heterotrophy
}

\author{
Mayrene O. Guimarais-Bermejo ${ }^{1}$, Martin Merino-Ibarra ${ }^{\text {Corresp., }}{ }^{2}$, Patricia M Valdespino-Castillo ${ }^{2}$, Fermín S \\ Castillo-Sandoval ${ }^{2}$, Jorge A Ramírez-Zierold ${ }^{2}$ \\ 1 Posgrado en Ciencias del Mar y Limnología, Universidad Nacional Autónoma de México, Ciudad Universitaria, Mexico \\ 2 Unidad Académica de Ecología y Biodiversidad Acuática, Instituto de Ciencias del Mar y Limnología, Universidad Nacional Autónoma de México, Ciudad \\ Universitaria, Mexico \\ Corresponding Author: Martin Merino-lbarra \\ Email address: mmerino@cmarl.unam.mx
}

Long-term and seasonal changes in production and respiration were surveyed in Valle de Bravo reservoir, Mexico, in a period during which high water-level fluctuations occurred (2006-2015). We assessed community metabolism through oxygen dynamics in this monomictic water-body affected by strong diurnal winds. The multiple-year data series allowed relationships with some environmental drivers to be identified, revealing that water level-fluctuations strongly influenced gross primary production and respiratory rates. Production and respiration changed mainly vertically, clearly in relation to light availability. Gross primary production ranged from 0.15 to $1.26 \mathrm{gO}_{2} \mathrm{~m}^{-2} \mathrm{~h}^{-1}$, respiration rate from -0.13 to $-0.83 \mathrm{gO}_{2} \mathrm{~m}^{-2} \mathrm{~h}^{-1}$ and net primary production from -0.36 to $0.66 \mathrm{gO}_{2} \mathrm{~m}^{-2} \mathrm{~h}^{-1}$ within the production layer, which had a mean depth of $5.9 \mathrm{~m}$ during the stratification periods and of $6.8 \mathrm{~m}$ during the circulations. The greater depth of the mixing layer allowed the consumption of oxygen below the production layer even during the stratifications, when it averaged $10.1 \mathrm{~m}$. Respiration below the production layer ranged from -0.23 to $-1.38 \mathrm{gO}_{2}$ $\mathrm{m}^{-2} \mathrm{~h}^{-1}$. Vertically integrated metabolic rates (per unit area) showed their greatest variations at the intra-annual scale (stratification-circulation). Gross primary production and Secchi depth decreased as the mean water level decreased between stratification periods. VB is a highly productive ecosystem; its gross primary production averaged $3.60 \mathrm{gC} \mathrm{m}^{-2} \mathrm{~d}^{-1}$ during the 10 years sampled, a rate similar to that of hypertrophic systems. About $45 \%$ of this production, an annual average net carbon production of $599 \mathrm{~g} \mathrm{C} \mathrm{m}^{-2}$ year-1, was exported to the hypolimnion, but on the average $58 \%$ of this net production was recycled through respiration below the production layer. Overall, only $19 \%$ of the carbon fixed in VB is buried in the sediments. Total ecosystem respiration rates averaged $-6.89 \mathrm{gC} \mathrm{m}^{-2} \mathrm{~d}^{-1}$ during 2006-2015, doubling the gross production rates. The reservoir as a whole exhibited a net heterotrophic balance continuously during the decade sampled, which means it has likely 
been a net carbon source, potentially releasing an average of $3.29 \mathrm{gC} \mathrm{m}^{-2} \mathrm{~d}^{-1}$ to the atmosphere. These results are in accordance with recent findings that tropical eutrophic aquatic ecosystems can be stronger carbon sources than would be extrapolated from temperate systems, and can help guide future reassessments on the contribution of tropical lakes and reservoirs to carbon cycles at the global scale. Respiration was positively correlated with temperature both for the stratification periods and among the circulations, suggesting that the contribution of $C$ to the atmosphere may increase as the reservoirs and lakes warm up owing to climate change and as their water level is reduced through intensification of their use as water sources. 
1 Metabolism in a deep hypertrophic aquatic ecosystem with high water-level fluctuations: a 2 decade of records confirms sustained net heterotrophy

3 Authors: Mayrene O. Guimarais-Bermejo ${ }^{1}$, Martín Merino-Ibarra ${ }^{2 *}$, Patricia M. Valdespino4 Castillo $^{2}$, Fermín S. Castillo-Sandoval ${ }^{2}$ and Jorge A. Ramírez-Zierold ${ }^{2}$

51 Posgrado en Ciencias del Mar y Limnología, Universidad Nacional Autónoma de México, Ciudad 6 Universitaria, México

72 Unidad Académica de Ecología y Biodiversidad Acuática, Instituto de Ciencias del Mar y Limnología, 8 Universidad Nacional Autónoma de México, Ciudad Universitaria, México

9 *Corresponding author: mmerino@cmarl.unam.mx

\begin{abstract}
Long-term and seasonal changes in production and respiration were surveyed in Valle de Bravo reservoir, Mexico, in a period during which high water-level fluctuations occurred (2006-2015). We assessed community metabolism through oxygen dynamics in this monomictic water-body affected by strong diurnal winds. The multiple-year data series allowed relationships with some environmental drivers to be identified, revealing that water level-fluctuations strongly influenced gross primary production and respiratory rates. Production and respiration changed mainly vertically, clearly in relation to light availability. Gross primary production ranged from 0.15 to $1.26 \mathrm{gO}_{2} \mathrm{~m}^{-2} \mathrm{~h}^{-1}$, respiration rate from -0.13 to $-0.83 \mathrm{gO}_{2} \mathrm{~m}^{-2} \mathrm{~h}^{-1}$ and net primary production from 0.36 to $0.66 \mathrm{gO}_{2} \mathrm{~m}^{-2} \mathrm{~h}^{-1}$ within the production layer, which had a mean depth of $5.9 \mathrm{~m}$ during the stratification periods and of $6.8 \mathrm{~m}$ during the circulations. The greater depth of the mixing layer allowed the consumption of oxygen below the production layer even during the stratifications, when it averaged $10.1 \mathrm{~m}$. Respiration below the production layer ranged from -0.23 to $-1.38 \mathrm{gO}_{2}$ $\mathrm{m}^{-2} \mathrm{~h}^{-1}$. Vertically integrated metabolic rates (per unit area) showed their greatest variations at the intra-annual scale (stratification-circulation). Gross primary production and Secchi depth decreased as the mean water level decreased between stratification periods. VB is a highly productive ecosystem; its gross primary production averaged $3.60 \mathrm{gC} \mathrm{m}^{-2} \mathrm{~d}^{-1}$ during the 10 years sampled, a rate similar to that of hypertrophic systems. About $45 \%$ of this production, an annual average net carbon production of $599 \mathrm{~g} \mathrm{C} \mathrm{m}^{-2}$ year $^{-1}$, was exported to the hypolimnion, but on the average $58 \%$ of this net production was recycled through respiration below the production layer. Overall, only $19 \%$ of the carbon fixed in VB is buried in the sediments. Total ecosystem respiration rates averaged $-6.89 \mathrm{gC} \mathrm{m}^{-2} \mathrm{~d}^{-1}$ during 2006-2015, doubling the gross production rates. The reservoir as a whole exhibited a net heterotrophic balance continuously during the decade sampled, which means it has likely been a net carbon source, potentially releasing an average of $3.29 \mathrm{gC} \mathrm{m}^{-2} \mathrm{~d}^{-1}$ to the atmosphere. These results are in accordance with recent findings that tropical eutrophic aquatic ecosystems can be stronger carbon sources than would be extrapolated from temperate systems, and can help guide future reassessments on the contribution of tropical lakes and reservoirs to carbon cycles at the global scale. Respiration was positively correlated with temperature both for the stratification periods and among the circulations, suggesting that the contribution of $\mathrm{C}$ to the atmosphere may increase as the reservoirs and lakes warm up owing to climate change and as their water level is reduced through intensification of their use as water sources.
\end{abstract}




\section{Introduction}

Ecosystem-scale metabolic rates represent an integrated measure of the ecosystem functioning in terms of organic matter production and consumption (Odum, 1971), and are fundamental metrics of the ecosystem (Hoellein et al. 2013). These integrated measures are needed to build regional and global balances of important biochemical elements, mainly oxygen and carbon (Raymond et al. 2013), which may be estimated through the oxygen dynamics linkage to photosynthesis and aerobic respiration. Yet our assessment of the contribution of epicontinental waters to global biogeochemical cycles is hindered by the variety of systems included (Lewis 2011). For example, it has been determined that $50 \%$ to $85 \%$ of the oxygen we breathe at planetary scale comes from oceanic primary production, but the global supply from inland waters has not yet been calculated (Downing, 2014). The recent re-evaluations of the contribution of epicontinental water bodies to global carbon balance (Cole et al., 2007; Alin and Johnson, 2007; Tranvik et al., 2009; Lewis, 2011; Raymond et al. 2013; Downing, 2014) illustrate the present controversy regarding its magnitude.

One of the main causes of the uncertainty regarding regional and global budgets is the scarcity of studies on carbon fluxes and community metabolism in tropical lakes and reservoirs (St. Louis et al. 2000; Staehr et al. 2012; Sarmento, 2012; Raymond et al. 2013; Almeida et al. 2016). Duarte and Prairie (2005) pointed out that most rivers and oligo- to mesotrophic lakes are likely carbon emission sources, a result confirmed by Hoellein et al. (2013) who found that $61 \%$ of the lakes they compared -mostly temperate- were heterotrophic. Furthermore, recent studies show that in eutrophic tropical water bodies the respiration can override production and can render them as significant sources of carbon emission (Gupta et al. 2008; Almeida et al. 2016; Räsänen et al. 2018). Because eutrophication ranks in first place among the problems faced by limnology, and it is expected to remain as the main issue in aquatic ecosystems in the future (Downing, 2014), it is important to study the metabolic balance of tropical eutrophic systems.

Climate change is another very important process affecting water bodies and their role in global cycles (Kosten et al. 2010). To address its effects and to better predict future trends, we need long-term monitoring of the metabolism of water bodies to assess metabolic variability at local and regional levels (Staehr et al., 2010; Sarmento, 2012; Solomon et al., 2013; Agusti et al. 2017). Long-term monitoring of whole ecosystems can help identify variations related to their environmental drivers, because they are likely to include significant variations of these drivers without the scaling problem of experimental assessments. Among these drivers, physical features are the least studied in relation to their effects on metabolism, in part due to the complexity of disentangling the simultaneous effects of multiple drivers (Hoellein et al. 2013, Coloso et al. 2011, Hararuk et al. 2018). Nutrients are among the main drivers of primary production in oligotrophic and mesotrophic conditions, hindering the identification of the effects of physical features. Because of this, in eutrophic and hypertrophic systems, where nutrient availability is not limiting, the effects of physical drivers may be easier to isolate and quantify (e.g. Coloso et al. 2011, Hararuk et al. 2018).

Water-level fluctuations are among the drivers of planktonic shifts and ecosystem functioning (Geraldes and Boavida, 2005; Wantzen et al., 2008; Mac Donagh et al., 2009; Zohary and Ostrovsky 2011; Kolding and van Zwieten, 2012; Valeriano-Riveros et al., 2014). However, relationships of these fluctuations with metabolic descriptors need clarification; one of their 
consequences might be the enhancement of boundary mixing events and hypolimnetic entrainment (Valdespino-Castillo et al., 2014; Ramírez- Zierold et al. 2015), which are aspects even more seldom approached in the tropics (Zohary and Ostrovsky 2011).

Because of this, in the present study we evaluate the long-term (2006-2015) dynamics of the production and respiration rates of a tropical, eutrophic reservoir exposed to high wide fluctuations in the water -level. We aim to identify the variability and trends of its metabolism and the role of physical drivers (water level, temperature and transparency). We also intend to gain insight into the role of this type of system in the carbon cycle, to provide data from tropical systems for national, regional and global scale carbon flux quantifications, and to provide information to improve the efficiency with which epicontinental aquatic systems are managed.

\section{Study area}

Valle de Bravo (VB) is a high-altitude (1830 $\mathrm{m}$ a.s.1) tropical reservoir in central Mexico $\left(19^{\circ} 21^{\prime} 30^{\prime \prime} \mathrm{N}, 100^{\circ} 11^{\prime} 00^{\prime \prime} \mathrm{W}\right)$ that receives water from a $546.9 \mathrm{~km}^{2}$ forested watershed. It is the largest reservoir $\left(18.55 \mathrm{~km}^{2}\right.$ surface area, mean depth $21.1 \mathrm{~m}$, maximum $38.6 \mathrm{~m}$ and a storage capacity of $391 \times 10^{6} \mathrm{~m}^{3}$ ) of the Cutzamala System (comprising seven reservoirs), which provides more than one-third of the water supply to the Mexico City Metropolitan Area (Ramírez-Zierold et al. 2010). During the past decade, water extraction for human use has caused wide variations in the water level (Valdespino-Castillo et al. 2014; Ramírez- Zierold et al. 2015), which has fallen by up to $12 \mathrm{~m}$ below the maximum capacity of the reservoir (Fig.1).

Climate in VB is sub-humid, warm to temperate with pronounced dry (November-May) and rainy (June-October) seasons. Mean monthly temperature ranges from $21.3{ }^{\circ} \mathrm{C}$ during May to $15.9{ }^{\circ} \mathrm{C}$ in the coldest month (January). The winter minimum varies depending on the number and intensity of cold fronts that reach the reservoir, with historic winter temperatures ranging from $8.1^{\circ}$ to $23.4^{\circ} \mathrm{C}$ during January. Mean annual precipitation is $836 \mathrm{~mm}$, and mean annual evaporation is $1620 \mathrm{~mm}$ (Ramírez-Zierold et al. 2010). Strong ( $7.4 \mathrm{~m} \mathrm{~s}^{-1}$ mean speed) diurnal (12:00-19:00 h) winds that blow along the two main valleys (Merino-Ibarra et al. 2008) make VB the most popular inland sailing resort in Mexico.

Because of this climatic pattern, the reservoir behaves as a warm monomictic lake; it remains stratified from March to October and circulates during the winter seasons ( November to $\sim$ February). During the stratification period the hypolimnion is anoxic, whereas during mixing the whole water column remains under-saturated (60\%) (Merino-Ibarra et al. 2008). This is likely due to its eutrophic condition, which is driven by increasing nutrient loads; these have reached up to $116.8 \mathrm{tP}_{\mathrm{P} e a \mathrm{r}^{-1}}$ and $557.1 \mathrm{t} \mathrm{N}$ year-1 (Ramírez-Zierold et al. 2010). As a result, nutrient concentrations in the reservoir have remained high since 2002 (Merino-Ibarra et al. 2008; Valdespino-Castillo et al. 2014); during 2002-2015, dissolved inorganic N (DIN) averaged $21.1 \mu \mathrm{M}$, and soluble reactive P (SRP) $0.71 \mu \mathrm{M}$ (Barjau-Aguilar 2018).

These concentrations are well above the limitation thresholds for phytoplankton (Reynolds 1999) and so far no evidence has been found of nutrient limitation of primary production in this eutrophic system (Merino-Ibarra et al. 2008; Valdespino-Castillo et al. 2014; Valeriano-Riveros et al. 2014). High chlorophyll $a(\mathrm{Chl} a)$ concentrations $\left(130-177 \mathrm{mg} \mathrm{m}^{-2}\right)$ and small Secchi depth $(1.2-2.5 \mathrm{~m}$; Valdespino-Castillo et al. 2014) found in VB are consistent with these findings. The plankton community in the reservoir changes in abundance and composition, only 
131

132

133

134

135

136

137

138

139

140

141

142

143

144

145

146

147

148

149

150

151

152

153

154

155

156

157

158

159

160

161

162

163

164

165

166

167

168

169

170

171

loosely in relation to periods of stratification and circulation. During the stratification period, phytoplankton is generally dominated by cyanobacteria, whereas during the circulation period diatoms are more likely to be dominant (Ramírez-García et al., 2002; Valeriano-Riveros et al. 2014). The zooplankton community is dominated by small-size species, particularly rotifers, as a consequence of cyanobacterial dominance (Nandini et al. 2008), although cladocerans and copepods are also present. Peaks of cladoceran biomass have been observed sometimes during the circulation period, when diatoms are dominant (Ramírez-García et al., 2002) and also during periods when water levels are low (Jiménez-Contreras et al. 2009).

Physical processes, mainly mixing events, likely play an important role for nutrient recycling, and plankton composition and metabolism in VB. The strong diurnal winds produce internal waves during the stratification period (Merino-Ibarra et al. 2008), and it has been suggested that -in combination with water level fluctuations - these waves enhance boundary-mixing events and hypolimnetic entrainment, particularly during the lower water levels, when the internal waves can interact with the bottom and shoreline (Ramírez-Zierold et al. 2015).

In a first analysis of the metabolic variations in VB during the initial year (August 2006 - August 2007) of this monitoring, Valdespino-Castillo et al. (2014) found that these water level fluctuations affected metabolic rates, particularly respiration, presumably because of their intensification of mixing. Furthermore, they concluded that the effect of mixing hindered the know effect of temperature over respiration when a single stratification-circulation cycle was analyzed. Similarly, in their analysis of the phytoplankton community in VB during 2008-2009, Valeriano-Riveros et al. (2014) found peaks of unexpected abundance of diatoms during the stratification periods, which they attributed to nutrient replenishment to the epilimnion due to boundary mixing events and hypolimnetic entrainment driven by the particularly low water levels of VB during 2008-2009 (Fig. 1).

Carbon burial rates have also been assessed in VB using sedimentary records and radiometric methods (Carnero-Bravo et al. 2014). These authors found that $\mathrm{C}$ flux to the sediments increased significantly after 1991, rising from a previous average of $174 \mathrm{~g} \mathrm{C} \mathrm{m}^{-2} \mathrm{y}^{-1}$ to an average of $250 \mathrm{~g}$ $\mathrm{C} \mathrm{m}^{-2} \mathrm{y}^{-1}$ ) between 1993 and 2005.

\section{Materials and methods}

\section{Environmental variables}

Samples were collected and incubated monthly from July 2006 to December 2015. Environmental parameters were determined before and after oxygen incubation, and then averaged. Temperature, dissolved oxygen concentration and its saturation were determined at 1 $\mathrm{m}$ vertical intervals down the full water column by means of a multi-parametric probe (Yellow Springs Instruments model 6600). Secchi depth was measured with a standard disk. Chl- $a$ concentrations were determined in water samples collected at the 1,2, 4,6 and $8 \mathrm{~m}$ depths in a Niskin bottle. Samples for Chl- $a$ were filtered with $0.45 \mu \mathrm{m}$ membranes (Millipore ${ }^{\mathrm{TM}}$ ), extracted with $90 \%$ acetone and determined with a spectrophotometer.

\section{Oxygen dynamics}


172 Oxygen evolution was quantified by incubations of light and dark bottles in situ following 173 Wetzel and Likens (1991) and Valdespino-Castillo et al. (2014). The oxygen incubations 174 approach to metabolism measurement has some important limitations, mainly that it is very labor intensive becaus containment artifacts (mainly if the required incubation time is long), and issues related to upscaling if samples are not representative (Staehr et al. 2012). In contrast, it has the advantage of involving a direct measurement of the process, and it does not require a quantification of the air-water oxygen flux (Staehr et al. 2012). Because of the strong winds, incubations are better suited for monitoring metabolism in VB than is free-water oxygen monitoring because of the impossibility of calculating the strong air-water exchange (Merino-Ibarra et al. 2008). This was verified in the analysis of the first year of monitoring (Valdespino-Castillo et al. 2014), during which the metabolic rates obtained were one order of magnitude higher than the errors of the method.

Samples and measurements were taken monthly at a central station (cf. Valeriano-Riveros et al. 2014 for the exact location); this is supported by the verification of horizontal homogeneity in the mixed layer of the reservoir (Nandini et al., 2008) due to intense daytime wind (MerinoIbarra et al., 2008). The bottles were incubated for 4 to 6 light-hours at depths of $0,1,2,4,8,12$, $20,24 \mathrm{~m}$, and as close to the bottom as possible, depending on the depth of the reservoir at the moment of sampling. At each depth, nine oxygen bottles were filled (three for initial oxygen determination, three for light incubation and three for dark incubation). During the sampling, extreme precautions were taken to completely avoid bubbling that could alter the oxygen, as recommended by Valdespino-Castillo et al. (2014). Dissolved oxygen concentration in each bottle was determined in the laboratory, in triplicate for each sample bottle to minimize and assess error (cf. Valdespino-Castillo et al. 2014 for further details on the method).

\section{Metabolism calculations}

Gross primary production (GPP), net primary production (NPP), and community respiration $(R)$ were calculated using the oxygen change rate in the light and dark bottles, respectively, following Wetzel and Likens (1991), therefore dividing the differences between initial and final oxygen concentrations by the specific incubation time of each set of bottles. Following Valeriano-Riveros et al. (2014), the depth of the production layer $\left(Z_{\mathrm{pl}}\right.$; assumed to end where GPP $=0$ ) was calculated using Secchi depth (SD). To do this, we analyzed the correlation between $\mathrm{SD}$ and the $\mathrm{GPP}=0$ depth in those production profiles in which this point was found in one of the sampled depths. The data fitted better when stratification and circulation data were separated, therefore two correlations (stratification and circulation) were obtained: a coefficient of $4.149\left(n=26, \mathrm{R}^{2}=0.85\right)$ for stratification, and $3.295\left(n=29, \mathrm{R}^{2}=0.90\right)$ for circulation. The corresponding coefficient was multiplied by SD to obtain $Z_{\mathrm{pl}}$ in those samplings in which it could not be easily identified in the vertical profile, because GPP $=0$ did not concur with one of the sampled depths.

To obtain area-based rates, volumetric rates were integrated over the production layer: the rate from each of the depths sampled was multiplied by the height of the water layer it represented. The same procedure was used when integrating $R$ rates below the production layer $\left(R_{\mathrm{bpl}}\right)$, which were integrated from $Z_{\mathrm{pl}}$ to the bottom of the reservoir during circulation, or to the depth where 
215 total anoxia was found during stratification. Both respirations $\left(R_{\mathrm{pl}}\right.$, respiration in the production 216 layer $)$ were added to obtain the total respiration $\left(R_{\text {Total }}=R_{\mathrm{pl}}+R_{\mathrm{bpl}}\right)$ for the full water column.

217 To calculate diel rates, the hourly production rates were multiplied by the corresponding

218

219

220

221

222

223

224

225

226

227

228

229

230

231

232

233

234

235

236

237

238

239

240

241

242

243

244

245

246

247

248

249

250

251

252

253

254

255 photoperiod for each sampling date at this latitude. In the case of diel respiration, the respiration during the night in the production layer was calculated by multiplying the nighttime hours by the dark respiration rate, conservatively estimated as $10 \%$ of the GPP rate following Geider and Osborne (1989). Below the production layer, diel respiration was assumed to be constant and was therefore estimated by multiplying $R_{\text {bpl }}$ by 24 hours. The proportion GPP: $R_{\text {Total }}$ in carbon units was used to assess the metabolic balance of the ecosystem as a whole.

Conversion of oxygen rates to carbon rates used the theoretical and most widely used conversion values PQ $=1.3$ and $R Q=1.0$ (Gazeau et al., 2005). The f-ratio (NPP/GPP), sensu Falkowski et al. (2003), was used to assess the fraction of the production that could potentially be exported from the production layer through the sinking of biomass).

\section{Data analyses}

Nutrient data from Barjau-Aguilar (2018) were used for preliminary assessment of the relations between nutrient availability and metabolic fluxes. To assess the effect of water-level fluctuations, we calculated the relative lake-level fluctuation index (RLLF) as proposed by Kolding and van Zwieten (2012, Equation 1). The RLLF is a simple empirical indicator defined as the mean amplitude of the annual or seasonal fluctuations in lake level divided by the mean depth of the lake or reservoir, times 100 . We calculated the RLLF both by year and by period (stratification and circulation) to identify the time scale in which water-level fluctuations exert the greatest influence on metabolism of the reservoir.

RLLF $=$ mean lake level amplitude/mean depth $* 100$

Contour diagrams were constructed in Surfer 11.0.642 (Golden Software, Inc.). The Kriging algorithm with the default linear variogram was used. For the temperature and oxygen diagrams (Figs. 2 and 3) a grid of 2632 x 108 was used in order to obtain point spacing of approximately 1 month on the horizontal axis and $1.1 \mathrm{~m}$ on the vertical axis. Vertical variation contours of the metabolic rates (Fig. 4) were obtained from monthly averages from the surface to $4 \mathrm{~m}$ for an average year, using a search ellipse of 4 months and $2 \mathrm{~m}$.

\section{Estimation of error propagation}

Errors and their propagation were determined according to classical error propagation theory $(\mathrm{Ku}, 1966)$. To obtain confidence intervals (CI) around our calculated variables, the standard error (SE) of the mean was converted directly to CI by multiplying with the t value for the desired alpha and specific degrees of freedom $(d f)$ for each case (Lehrter and Cebrian 2010).

Since our calculations required only sums, products and quotients, we used the simplified equations proposed by those authors for simple step-by-step calculations, where $\mathrm{SE}_{\mathrm{W}}$ is the $\mathrm{SE}$ of a function $W$ calculated from the means of two or more variables (i.e., $W=f(\bar{U}, \bar{V})$ ). For the sum we used equation (2) and equation (3) for products and quotients: 
256

257

258

259

260

261

262

263

264

265

266

267

268

269

270

271

272

273

274

275

276

277

278

279

280

281

282

283

284

285

286

287

288

289

$$
\mathrm{SE}_{W}=\sqrt{\left(a \mathrm{SE}_{\bar{U}}\right)^{2}+\left(b \mathrm{SE}_{\bar{V}}\right)^{2}}
$$

These equations assume that the means involved in the calculation follow a normal distribution, which was checked with the data. Propagation of the degrees of freedom $(d f)$ from the metabolic rates used equation (4) adapted by Lehrter and Cebrian (2010) from the Welch-Satterthwaite formula $(\mathrm{Ku}, 1966)$.

$$
\mathrm{df}_{W}=\frac{\mathrm{SE}_{W}^{4}}{\sum_{i=1}^{j} \frac{c_{i}^{4} \mathrm{SE}_{\bar{W}_{i}}^{4}}{\mathrm{df}_{\bar{W}_{i}}}}
$$

\section{Results}

Because metabolic measurements are done on a volumetric basis and then have to be integrated, first vertically, then for the $24 \mathrm{~h}$ period, and finally converted to carbon units, results are here presented sequentially, from the most simple data (i.e. environmental) to the final integrated measurements and their correlation with physical drivers, to address the main question of this paper: how the metabolism of an hypertrophic tropical reservoir behaves in the face of variations in water level and temperature.

\section{Environmental parameters}

Temperature in VB ranged during 2006-2015 between 17.7 and $23.9^{\circ} \mathrm{C}$. Thermal stratification occurred every year, with averages of $22.3^{\circ} \mathrm{C}$ during stratification and $19.9{ }^{\circ} \mathrm{C}$ in the circulation (Figure 2). Mean epilimnetic temperatures were always above $22.5^{\circ} \mathrm{C}$ during the summer (JunSep, well-established stratification). The lowest temperatures $\left(17.3-19.0^{\circ} \mathrm{C}\right)$ were found in January and February, during the circulation period. These minimal temperatures varied considerably among the years sampled, reaching a minimum during the circulation of 2010-2011 (mean $18.77^{\circ} \mathrm{C}$ ), and a maximum in the $2013-2014$ circulation period (mean $20.07^{\circ} \mathrm{C}$ ) (Table 1).

The vertical distribution of oxygen found in VB during 2006-2015 (Figure 3) sharply outlined the monomictical behavior of VB. During the stratification, dissolved oxygen concentrations were close to saturation $\left(\sim 8 \mathrm{mg} \mathrm{L}^{-1}\right)$ from the surface down to $\sim 6 \mathrm{~m}$ and thence declined abruptly down to $\sim 10 \mathrm{~m}$ depth, below which an anoxic hypolimnion was found. In contrast, during circulation, oxygen concentrations were nearly homogeneous throughout the water column but remained under saturated (50-80\%). Because of this sharp contrast between stratification and circulation, we used the oxycline -and in particular the $1.0 \mathrm{mg} \mathrm{L}^{-1}$ oxygen isoline- as a proxy for the depth of the functional mixing layer $\left(Z_{\mathrm{mix}}\right)$ in VB (Figure 3 ), following 
290 Catalan and Rondón (2016). $Z_{\text {mix }}$ ranged between 8 and $13 \mathrm{~m}$ during the stratification periods and 291 deepened to the bottom of the reservoir during most of the circulation periods. Secchi disk

292

293

294

295

296

297

298

299

300

301

302

303

304

305

306

307

308

309

310

311

312

313

314

315

316

317

318

319

320

321

322

323

324

325

326

327

328

329

330

transparency varied generally from $\sim 1 \mathrm{~m}$ during stratification to $\sim 2 \mathrm{~m}$ during circulation (Table 1), although it extraordinarily reached $6.3 \mathrm{~m}$ (December 2010). The depth of the production layer $\left(Z_{\mathrm{pl}}\right)$, also shown in Figure 3, averaged $5.9 \mathrm{~m}$ during stratification and $6.8 \mathrm{~m}$ during circulation. Chl- $a$ concentrations averaged $11.6 \mu \mathrm{g} \mathrm{L}^{-1}$ overall in VB during the period sampled. The mean concentration during the stratification periods $\left(12.2 \mu \mathrm{g} \mathrm{L}^{-1}\right)$ was higher than during the circulation periods sampled $(10.7 \mu \mathrm{g} \mathrm{L}-1$, Table 1$)$, but the difference was not statistically significant because variability among periods was high.

Vertical variations of the metabolic rates $\left(\mathrm{gO}_{2} \mathrm{~m}^{-3} \mathrm{~h}^{-1}\right)$

As expected, metabolic rates exhibited strong vertical gradients. Figure 4 summarizes these gradients and their annual variations by plotting the mean monthly rates at each depth to obtain the average annual pattern for 2006-2015. Average production (both net and gross) rates were maximal around the $1 \mathrm{~m}$ depth $\left(0.09-0.14 \mathrm{gO}_{2} \mathrm{~m}^{-3} \mathrm{~h}^{-1}\right.$ for NPP, and $0.15-0.20 \mathrm{gO}_{2} \mathrm{~m}^{-3} \mathrm{~h}^{-1}$ for GPP) throughout the year, and diminished rapidly and relatively regularly below this depth, clearly in relation to the decrease in light availability. The maximum was higher during the stratification months, from April to July, and showed a secondary maximum around the onset of the circulation period, between September and November. The maximum was smaller and less evident during the central months of the circulation period, December and January, when the vertical variation of production rates was also smaller. The highest variability of production through time was observed in the surface (Fig. 4), where averages ranged from $<0.06$ to $>0.14$ $\mathrm{gO}_{2} \mathrm{~m}^{-3} \mathrm{~h}^{-1}$ for NPP, and from $<0.11$ to $>0.19 \mathrm{gO}_{2} \mathrm{~m}^{-3} \mathrm{~h}^{-1}$ for GPP. Respiration also had a vertical gradient, and was maximal (around $-0.06 \mathrm{gO}_{2} \mathrm{~m}^{-3} \mathrm{~h}^{-1}$, Fig. $4 \mathrm{~b}$ ) at the surface and down to $1 \mathrm{~m}$, presumably as a result of photic stress and photorespiration.

\section{Vertically integrated metabolic rates $\left(\mathrm{gO}_{2} \mathrm{~m}^{-2} \mathrm{~h}^{-1}\right)$}

Once vertically integrated for the whole production layer, metabolic rates could be graphically depicted for the full period sampled to show the temporal heterogeneity of production and consumption of oxygen (Fig. 5a). The depth of the production layer $\left(Z_{\mathrm{pl}}\right)$, to which the rates were integrated, ranged from 3 to $21 \mathrm{~m}$ (Fig. 3). Hourly GPP rates ranged from 0.15 to $1.26 \mathrm{gO}_{2} \mathrm{~m}^{-2} \mathrm{~h}-$ , oxygen consumption from -0.13 to $-0.83 \mathrm{gO}_{2} \mathrm{~m}^{-2} \mathrm{~h}^{-1}$ and NPP from -0.36 to $0.66 \mathrm{gO}_{2} \mathrm{~m}^{-2} \mathrm{~h}^{-1}$ (Fig. 5a). The three rates showed variability between samplings, but a relative long-term stability.

Oxygen consumption below the production layer $\left(R_{\mathrm{bpl}}\right)$ ranged from -0.23 to $-1.38 \mathrm{gO}_{2} \mathrm{~m}^{-2} \mathrm{~h}^{-1}$. $R_{\mathrm{bpl}}$ rates during the stratification periods were similar to the production layer values, and the highest rates occurred during the circulation periods (Fig. 5b), when they were integrated from $Z_{\mathrm{pl}}$ to the bottom of the reservoir. When the respiration of both layers was considered, the resulting total respiration $\left(R_{\text {Total }}\right)$ for the water column of VB ranged from -0.28 to $-2.11 \mathrm{gO}_{2} \mathrm{~m}^{-}$ ${ }^{2} \mathrm{~h}^{-1}$, and the highest rates also occurred during the circulation periods. 
331

332

333

334

335

336

337

338

339

340

341

342

343

344

345

346

347

348

349

350

351

352

353

354

355

356

357

358

359

360

361

362

363

364

365

366

367

368

369

370

371

372

373

\section{Metabolic balance and carbon flux}

To assess the metabolic balance and carbon flows, daily rates (24 h-integrated) were considered (Table 2). Although during the daytime the production layer was most of the time autotrophic, when the nighttime respiration was also considered the production layer was sometimes heterotrophic on a daily basis, particularly during the circulation samplings. Moreover, when the respiration from the layer below the production layer $\left(R_{\mathrm{bpl}}\right)$ was also considered, VB as a whole was net heterotrophic throughout the studied period. In fact, the GPP: $R_{\text {Total }}$ ratio (in $\mathrm{C}$ units) of the reservoir ranged from 0.07 to 0.93 and averaged 0.52 for the full 2006-2015 period (Figure $6)$. Although it indicated heterotrophy throughout the full period, the GPP: $R_{\text {Total }}$ ratio also showed a very slight long-term trend with an increase of $0.02 \mathrm{y}^{-1}$ (Mann-Kendall trend test, $\mathrm{p}<0.01)$.

In terms of carbon fluxes, GPP showed VB to be a very productive system, with an average C fixation of $3.60 \mathrm{gC} \mathrm{m}^{-2} \mathrm{~d}^{-1}$ during the 10 years sampled (Table 2). The NPP averaged $1.64 \mathrm{gC} \mathrm{m}^{-}$ ${ }^{2} \mathrm{~d}^{-1}$, so the potential carbon exportation from the production layer through biomass sinking $(\mathrm{f}=\mathrm{NPP} / \mathrm{GPP})$ of VB averaged $45 \%$ (Table 3 ) and was higher during the stratification periods $(48 \%)$ than during the circulation periods $(40 \%)$. On the annual scale, our measurements of NPP ranged from 258 to $892 \mathrm{~g} \mathrm{C} \mathrm{m}^{-2} \mathrm{y}^{-1}$ and averaged $588 \mathrm{~g} \mathrm{C} \mathrm{m}^{-2} \mathrm{y}^{-1}$. When compared to the more recent carbon burial rates reported for VB $\left(250 \mathrm{~g} \mathrm{C} \mathrm{m}^{-2} \mathrm{y}^{-1}\right.$; Carnero-Bravo et al. 2014), the estimated recycling efficiency in the water column of VB would average $58 \%$ of the annual NPP and would have ranged from $3 \%$ to $72 \%$ in the years 2006 to 2015 . This means that on the average, only $19 \%$ of the total annual $1344 \mathrm{~g} \mathrm{C} \mathrm{m}^{-2} \mathrm{y}^{-1}$ fixed in $\mathrm{VB}$ would be sequestered in the sediments, and most of the potential carbon burial would be remineralized back to the water column. Overall, the system's total respiration rate was higher than GPP or NPP, averaging -6.89 $\mathrm{gC} \mathrm{m}^{-2} \mathrm{~d}^{-1}$, which in steady state would imply a potential net carbon release of $-3.29 \mathrm{gC} \mathrm{m}^{-2} \mathrm{~d}^{-1}$ to the atmosphere on average during 2006-2015.

\section{Correlations with environmental drivers}

Overall, although highly variable among samplings, metabolic rates showed significant differences between the stratification and circulation periods. Total respiration $\left(R_{\text {Total }}\right)$ rates were significantly $(\mathrm{p}<0.01)$ higher $\left(1.11 \mathrm{gO}_{2} \mathrm{~m}^{-2} \mathrm{~h}^{-1}\right)$ during circulation than during stratification $(0.73$ $\left.\mathrm{gO}_{2} \mathrm{~m}^{-2} \mathrm{~h}^{-1}\right) . R_{\mathrm{bpl}}$ rates were also significantly $(\mathrm{p}<0.01)$ higher $\left(0.77 \mathrm{gO}_{2} \mathrm{~m}^{-2} \mathrm{~h}^{-1}\right)$ during circulation than during stratification $\left(0.42 \mathrm{gO}_{2} \mathrm{~m}^{-2} \mathrm{~h}^{-1}\right)$, while $R_{\mathrm{pl}}$ rates showed a similar pattern, but the differences were not statistically significant $(\mathrm{p}<0.33)$.

In contrast, production rates showed the opposite pattern. NPP rates were higher $\left(0.31 \mathrm{gO}_{2} \mathrm{~m}^{-2} \mathrm{~h}^{-}\right.$ $\left.{ }^{1}\right)$ during the stratification than during the circulation $\left(0.26 \mathrm{gO}_{2} \mathrm{~m}^{-2} \mathrm{~h}^{-1}\right)$ and this was also a statistically significant difference $(\mathrm{p}<0.04)$. GPP rates were also slightly higher $\left(0.63 \mathrm{gO}_{2} \mathrm{~m}^{-2} \mathrm{~h}^{-1}\right)$ during the stratification than during the circulation $\left(0.60 \mathrm{gO}_{2} \mathrm{~m}^{-2} \mathrm{~h}^{-1}\right)$, but this difference was not statistically significant $(\mathrm{p}<0.20)$

Significant correlations among the rates and the environmental drivers considered were also obtained for each of the two limnological conditions of the reservoir. GPP and NPP did not correlate significantly with temperature, but respiration did correlate positively for both periods. For the stratification periods, $R_{\mathrm{bpl}}$ showed a high and significant positive correlation $\left(\mathrm{r}^{2}=0.452\right.$, $\mathrm{p}<0.05)$ with temperature. For the circulation periods, when respiration occurs throughout the 
374

375

376

377

378

379

380

381

382

383

384

385

386

387

388

389

390

391

392

393

394

395

396

397

398

399

400

401

402

403

404

405

406

407

408

409

410

411

412

413

414

415

416

417

water column (Fig. 7), $R_{\text {Total }}$ also correlated positively $\left(\mathrm{r}^{2}=0.314, \mathrm{p}<0.12\right)$ with the mean water column temperature, which varied between years depending on each winter's conditions, as described earlier.

For the stratification periods, significant correlations were also found with the water level index RLLF (higher values of RLLF mean wider water-level fluctuation and lower levels below reservoir capacity). In particular, Secchi depth showed a significant inverse correlation with RLLF $\left(\mathrm{r}^{2}=0.569, \mathrm{p}<0.04\right)$. GPP also showed an inverse correlation $\left(\mathrm{r}^{2}=0.393, \mathrm{p}<0.07\right)$, although the correlations were much less significant during circulation or at the annual scale. Metabolic rates showed significant correlations with nutrients only during the stratification periods. GPP correlated inversely with total $\mathrm{P}\left(\mathrm{r}^{2}=0.078, \mathrm{p}<0.02\right)$ and with total $\mathrm{N}\left(\mathrm{r}^{2}=0.124, \mathrm{p}<0.004\right)$. NPP only correlated with total $\mathrm{N}\left(\mathrm{r}^{2}=0.129, \mathrm{p}<0.003\right) . R_{\mathrm{bpl}}$ did not correlate with either $\mathrm{P}$ or $\mathrm{N}$.

\section{Discussion}

The time series here analyzed reveals considerable impact of physical factors (particularly those associated with fluctuations in water level) on the metabolic rates and the overall heterotrophic behavior of the system. Multiple processes likely occur associated with fluctuations in water level, in a complex interaction where significant vertical changes of metabolism are determinant. Metabolic rates in VB had strong vertical gradients that are likely related to the rapid absorption of light in this eutrophic system, where Secchi disk transparency is generally within 1-2 m. This emphasizes the importance of including detailed vertical sampling in metabolic studies of water bodies, an approach that has been overlooked in many studies (See Table 4). Besides providing insight into vertical changes themselves, detailed vertical measurement of production and respiration rates is important in obtaining realistic and representative area-based integrations, useful for assessing exchange fluxes of water bodies with the atmosphere and sediments (Valdespino-Castillo et al. 2018). We estimate that integrated rates can be biased by up to one order of magnitude when based on single-depth measurements.

In VB, the vertical variation of metabolic rates was closely coupled to the vertical changes in limnological parameters and processes. The sharp decrease of production within a few meters is likely caused by the sharp decrease in light availability in this ecosystem where Secchi depth is on average only $1.7 \mathrm{~m}$. The fact that suspended solids in VB have previously been reported to be low (1-6 $\left.\mathrm{mg} \mathrm{l}^{-1}\right)$ and mainly organic (Olvera-Viascán et al. 1998) suggests that this light limitation is likely an effect mainly of self-shading by the planktonic community itself. Selfshading is very probably due to the very high Chl-a concentrations found in VB, which have been recorded to reach up to $88 \mathrm{mg} \mathrm{m}^{-3}$ (Merino et al. 2008). This is also supported by the fact that the production layer is always contained (mean $Z_{\mathrm{pl}}=6.2 \mathrm{~m}$ ) within the mixed layer (mean $Z_{\mathrm{mix}}=10.1 \mathrm{~m}$ during stratification and $22.7 \mathrm{~m}$ during circulation periods; Figs. 3 and 7).

The separation between the depths of these two layers allows the existence of a broad aerobic respiration layer in $\mathrm{VB}$, in which there is not enough light for photosynthesis, but there is still oxygen that is supplied by the mixing processes of the surface layer. During the stratification months, this respiration layer is in the deeper half of the epilimnion, but during circulation periods it extends all the way to the reservoir bottom (Figs. 3 and 7). It is notable that the respiration in this layer outbalances the otherwise autotrophic production layer of this highly eutrophic system. This net heterotrophic character of the ecosystem is likely due to the high nutrient and organic load it receives (Ramirez-Zierold et al. 2010), in agreement with the 
418 findings of Solomon et al. (2013) that both allochthonous organic matter inputs from the 419 watershed, and excess autochthonous production driven by nutrient enrichment, increase 420 background respiration in lakes. Although data on the organic matter content of the water

421

422

423

424

425

426

427

428

429

430

431

432

433

434

435

436

437

438

439

440

441

442

443

444

445

446

447

448

449

450

451

452

453

454

455

456

457

458

459

460

461

462 column of VB have not been published, using the dissolved organic nitrogen measurements done by Barjau-Aguilar (2018), we estimate the mean DOC to have been $7.67 \mathrm{mg} \mathrm{L}^{-1}$ at VB during the period studied. This value is well above the $5 \mathrm{mg} \mathrm{L}^{-1}$, suggested as a threshold for the transition between net autotrophy and net heterotrophy in lakes (Sobek et al. 2007), so it is consistent with the net heterotrophy we find in VB. Such an amount of organic matter is probably a factor in the oxygen under-saturation found in VB during the circulation periods. Because the organic load to VB is high (Ramirez-Zierold et al. 2010), allochthonous organic matter may be causing a background respiration (Solomon et al. 2013) high enough to override the supply of oxygen by mixing.

\section{Limnological processes}

The vertical distribution of temperature in VB found during 2006-2015 confirms the continuity of a monomictic behavior of the reservoir, as found before 2006 (Merino-Ibarra et al. 2008;

Ramirez-Zierold et al. 2010) in spite of the drastic water-level decreases that occurred during this period. Functional thermal stratification occurred every year, although the thermocline gradient was small $\left(\leq 0.4{ }^{\circ} \mathrm{C} \mathrm{m}^{-1}\right)$, as expected for tropical lakes (Catalan and Rondón 2016).

Hypolimnetic temperatures increased in VB during each stratification period during 2006-2015, confirming the persistence of this trend in VB during the stratification, as reported for previous years (Merino-Ibarra et al. 2008; Ramirez-Zierold et al. 2010). Maximum temperatures in the hypolimnion occurred during the stratification periods when the water level of the reservoir was lowest (i.e. in 2008, 2009 and 2013, Fig. 2), supporting the suggestion (Ramirez-Zierold et al. 2015) that the rate of hypolimnetic warming is related with the magnitude of the water level decrease. Additionally, the 2006-2015 time series here described also shows the interannual variability of temperature in VB, particularly during the circulation periods, when the full water column is affected by heat exchange through the surface, and the water temperature is likely to be directly related to the coldness of each winter.

Oxygen vertical distribution was consistent with the temperature distribution and the monomictic behavior confirmed for VB during the decade sampled. As suggested for tropical eutrophic systems (Catalan and Rondón 2016), we find that oxygen is a better descriptor of the limnological cycle of VB than is temperature. The mainly anoxic hypolimnions (Figure 3 ) offer a clear representation of the system's monomictic behavior and its sustained eutrophic condition. Therefore, we concur with Catalan and Rondón (2016) that this possibility should be considered for other tropical eutrophic systems, where vertical variations of oxygen are sharper than vertical variations of temperature.

Secchi depth was also a simple but very useful tool to extend the assessment of the vertical range of production $\left(Z_{\mathrm{pl}}\right)$ throughout the full sampled period (Figure 3). In particular, correlations between SD and GPP $=0$ allowed the depth where GPP equals zero to be modeled; this was frequently a depth where experimental incubations were not performed, in spite of the effort we applied to resolve vertical variations through incubating at up to 8 different depths. Hence, the use of Secchi depth to estimate $Z_{\mathrm{pl}}$ can be a useful tool to manage large datasets containing vertical assessments of GPP and $R$, and to improve their yield of integrated rates. It is notable that among the metabolic studies in tropical lakes or reservoirs summarized in Table 4, fewer 
463 than half report on the measurement of metabolism at multiple water depths, and only 1 in 4 464 reports on the determination of the depth of the production layer. This demonstrates the need for 465 studies that deal in detail with vertical variations of the metabolic rates and therefore offer 466 reliable integrated rates.

467

\section{Effects of temperature and water-level fluctuations on metabolic rates}

469

470

471

472

473

474

475

476

477

478

479

480

481

482

483

484

485

486

487

488

489

490

491

492

493

494

495

496

497

498

499

500

501

502

503

504

505

506
Although temperature is the ultimate driver of metabolic rates at organism level, at the ecosystem scale its effect can be hindered by the many other changes that can occur simultaneously. In particular, (unlike marine systems, cf. Downing, 2014), monomictic inland systems exhibit contrasting physicochemical conditions coupled to the seasonal variations of temperature, which are mainly dependent on the variable intensity and spatial extent of mixing processes. These conditions include: the formation of an anoxic hypolimnion where aerobic respiration can not occur; the transport of plankton across light boundaries during full circulation; and the exposure of reduced compounds to oxidizing conditions and/or the transport of nutrients associated with boundary mixing and hypolimnetic entrainment (Ramirez-Zierold et al. 2010, 2015).

All of these processes and conditions can affect production and respiration rates, hindering the effect of concomitant temperature changes. This apparently was the case in the initial assessment of Valdespino et al (2014), who did not find a significant positive correlation between respiration and temperature in tests of 2006-2007 stratification data, or even of annual data for VB. Valdespino et al. (2014) attributed this to the dominance of the effect of mixing on respiration over that of temperature when stratification and circulation data were assessed together. In contrast, the long-term data now reported reveal a positive correlation of respiration with temperature when circulation and stratification periods were analyzed separately. In the case of the circulations, having data from a series of years allowed enough thermal variability to reveal the expected direct effect of temperature on metabolic rates, and particularly on respiration. Additionally, this expected correlation could also be identified in the case of the stratifications within the lower part of the epilimnion (Fig. 7), where the effects of daily wind mixing would be smaller than in the rest of the epilimnion.

Because of the wide water-level fluctuations in VB during 2006-2015, this data set allowed assessment of the effects of these variations, parameterized here as RLLF. Water level decreases may increase the frequency and intensity of boundary mixing events and hypolimnetic entrainment during stratification in VB (Ramirez-Zierold et al. 2010, 2015). In turn, it has also been shown by Valeriano-Riveros et al. (2014) that increased boundary mixing favors diatoms over noxious cyanobacteria (Nostocales), owing both to mixing itself and to the nutrient inputs involved. This would mean that water-level fluctuations could affect the food web through changes in mixing. In fact, Jiménez-Contreras (2009) also found significant variation in the composition of the zooplankton community, observing that the dominance of rotifers over cladocerans inverted during low-level periods, changing from a short microbial loop to a longer food web. Hence, the impact of water-level fluctuations on metabolic rates likely involves its effect over multiple processes, including mixing itself, changes in the planktonic food web and an increase in nutrient availability to the surface layer.

In our 2006-2015 metabolic data set, where ten stratifications with different water levels could now be compared, both Secchi depth and GPP decreased significantly as a function of the RLLF. 
507 The decrease of Secchi depth could be due to the increase in nutrient supply to the surface layer 508 through hypolimnetic entrainment and boundary mixing, where nutrients might be limiting the 509 expansion of phytoplankton. That there may be a certain degree of nitrogen limitation during the

510

511

512

513

514

515

516

517

518

519

520

521

522

523

524

525

526

527

528

529

530

531

532

533

534

535

536

537

538

539

540

541

542

543

544

545

546

547

548

549

stratification in VB was suggested by Valeriano-Riveros et al. (2014) and this view is also supported by the low but significant positive correlation we obtained between NPP and TN.

Another process that could be causing decreased Secchi depth and GPP during periods of lower water-levels could be resuspension of fine sediment along the new shorelines; sediments that had settled under conditions of higher water levels would be increasingly exposed as water levels fell. The energy needed for this is available at VB, where strong winds blow daily, but the relative abundance of the sediments suspended in the water column under different water-level conditions still needs to be measured to verify the importance of this possibility.

In either case, these results are consistent with those previously found by Valdespino-Castillo et al. (2014) who concluded that sharp water level decreases may shift the community metabolism from autotrophy towards heterotrophy. Altogether, this pattern is also important to direct the needed reassessment of the contribution of reservoirs and lakes to the global carbon cycle (Cole et al., 2007; Tranvik et al., 2009; Lewis, 2011; Raymond et al. 2013; Downing, 2014), because it shows that lowering of the level would cause a decrease in the net carbon sequestration of deep stratified systems.

\section{Metabolic balance, spatial and temporal long-term trends}

The high GPP found in VB throughout the decade confirms that it has remained a very productive system, in spite of the wide water-level fluctuations and other changes. In fact, its $\mathrm{C}$ fixation rates are higher that those found during the initial assessment of 2006-2007 and are now within the range $\left(2.7-5.0 \mathrm{gC} \mathrm{m}^{-2} \mathrm{~d}^{-1}\right)$ of other tropical epicontinental water bodies considered hypertrophic (e.g. Oloiden in Kenya, Lake Conway in Florida, McIlwaine in Zimbabwe, Pao Caniche in Venezuela, and Shahidullah Hall in Bangladesh, Table 4), but not yet as high as, for example, the highly hypertrophic Lake Xolotlán in Nicaragua. Hence, our results in terms of primary production indicate that VB would now be more accurately classified as hypertrophic than as eutrophic.

Although productivity in VB is high, and nearly half of it is net production -which can be exported from the production layer to the sediments and become sequestered $\mathrm{C}$ - our respiration data and the comparison with net $\mathrm{C}$ burial assessed through independent radiometric methods of Carnero-Bravo et al. (2014) indicate that most of this carbon is remineralized and only about $40 \%$ of the NPP is permanently buried in the sediments of this ecosystem.

Furthermore, because the total respiration in this ecosystem is also very high -nearly doubling GPP rates- the system has a net heterotrophic metabolism. These results are consistent with the findings of Gupta et al. (2008), Almeida et al. (2016) and Räsänen et al. (2018) and confirm now with a long-term data set- that tropical hypertrophic reservoirs can be highly productive and simultaneously be important sources of atmospheric emissions; these emissions may be larger than the burial of organic carbon in their sediments, because of high rates of mineralization in the water column and sediments, as occurs in VB. These findings indicate that the pattern found for temperate systems by Duarte and Prairie (2005) and Hoellein et al. (2013) may also take place in eutrophic reservoirs. More metabolic studies on tropical systems that include detailed 
550

551

552

553

554

555

556

557

558

559

560

561

562

563

564

565

566

567

568

569

570

571

572

573

574

575

576

577

578

579

580

581

582

583

584

585

586

587

588

589

590

measurements of vertical variation and respiration are needed, to reassess the contribution of epicontinental water bodies to global carbon balance (Cole et al., 2007; Alin and Johnson, 2007; Tranvik et al., 2009; Lewis, 2011; Raymond et al. 2013; Downing, 2014).

It is expected that long-term data will be key to assessing metabolic variability (Staehr et al., 2010; Sarmento, 2012; Solomon et al., 2013) in the possible scenarios of climate change (Kosten et al. 2010). Our results show that a decade of metabolic records can be enough to start identifying trends, as recently found by Agusti et al. (2017). Furthermore, the correlations found here with environmental drivers allow the exercise of simple predictions for VB that can inform global expectations. For instance, our results indicate that for each $1^{\circ} \mathrm{C}$ increase in the lake temperature its respiration and $\mathrm{C}$ emission could further increase by $0.4-0.9 \mathrm{gC} \mathrm{m}^{-2} \mathrm{~d}^{-1}$; this is consistent with the findings of Kosten et al. (2010) on $\mathrm{CO}_{2}$ emission from lakes, and suggests one of the negative feedbacks between climate change and eutrophication that could be expected in heterotrophic tropical systems. Similarly, our results on the inverse relationship between GPP and water level decrease (RLLF) also demonstrate that the water deficiency expected for the latitude of VB -if coupled with the intensification of its use as a source of fresh water - could enhance its role as a carbon source, a process that may also occur in the numerous water reservoirs that will be more intensively used throughout similar latitudes.

\section{Conclusions}

Production and respiration records for VB over the course of a decade show that high respiration of eutrophic tropical reservoirs can surpass their high production and carbon burial rates, and therefore these reservoirs likely act as important atmospheric carbon sources. Temperature and water level variations significantly affect metabolic rates in VB. Mixing, food web changes and nutrient limitation likely play a role that needs to be further investigated. The metabolism of more tropical systems must be studied, in order to improve global budgets, and to build more long-term series to support the prediction of future trends. Our results point to an increase in net heterotrophy of deep eutrophic reservoirs as temperatures increase and as their water levels fluctuate in response to climate change and increased exploitation of their water for human use.

\section{Acknowledgements}

This paper is part of the requirements for the PhD Degree for M. Guimarais. We aknowledge field support from lake users, mainly ProValle A.C. Club Náutico Avandaro and Club Naútico Marina Azul, Gloria Vilaclara and students of the Laboratory of Aquatic Biogeochemistry. We thank Adan Zuñiga for the processing of the Surfer figures, Ann Grant and M. Macek for comments on the manuscript.

\section{References}

Agusti, S., Martinez-Ayala, J., Regaudie-de-Gioux, A. and Duarte, C.M., 2017. Oligotrophication and metabolic slowing-down of a NW Mediterranean coastal ecosystem. Frontiers in Marine Science, 4, p.432. doi: $10.3389 /$ fmars. 2017.00432 
591

592

593

594

595

596

597

598

599

600

601

602

603

604

605

606

607

608

609

610

611

612

613

614

615

616

617

618

619

620

621

622

623

624

625

626

627

628

629

Alin, S. and Johnson, T.C. 2007. Carbon cycling in large lakes of the world: A synthesis of production, burial, and lake-atmosphere exchange estimates. Global Biogeochemical Cycles, 21:1-12.

Allanson, B. R., Hart, R. C., O’Keeffe, J. H. and Robarts, R. D. 1990. Primary producers and their production in lakes and reservoirs. In: Inland Waters of Southern Africa: An Ecological Perspective (pp. 221-284). Springer, Dordrecht.

Almeida, R.M., Nóbrega, G.N., Junger, P.C., Figueiredo, A.V., Andrade, A.S., de Moura, C.G., Tonetta, D., Oliveira Jr, E.S., Araújo, F., Rust, F. and Piñeiro-Guerra, J.M., 2016. High primary production contrasts with intense carbon emission in a eutrophic tropical reservoir. Frontiers in microbiology, 7: 717-740, doi: 10.3389/fmicb.2016.00717

Amarasinghe, P. B. and Vijverberg, J. 2002. Primary production in a tropical reservoir in Sri Lanka. Hydrobiologia, 487(1), 85-93.

Awortwi, F. E. 2010. "Spatio-temporal variability of phytoplankton community species composition, biomass and primary productivity of Lake Bosomtwe (Ghana)". PhD Thesis. College of Health Sciences. KNUST, Kumasi, Ghana, 200 p.

Barjau-Aguilar, M. 2018. "N and P internal net processes from mass blances in a eutrophic reservoir during 2002-2015”. Ms. Thesis, Universidad Nacional Autónoma de México. 92 p.

Catalan, J. and Rondón, J.C.D., 2016. Perspectives for an integrated understanding of tropical and temperate high-mountain lakes. Journal of Limnology, 75(s1): 215-234.

Carnero-Bravo, V., Merino-Ibarra, M., Ruiz-Fernández, A.C., Sanchez-Cabeza, J.A. and Ghaleb, B. 2014. Sedimentary record of water column trophic conditions and sediment carbon fluxes in a tropical water reservoir (Valle de Bravo, Mexico). Environmental Science and Pollution Research, 22(6):4680-94.

Cole, J.J., Prairie, Y.T., Caraco, N.F., McDowell, W.H., Tranvik, L.J., Striegl, R.G., Duarte, C.M., Kortelainen, P., Downing, J.A., Middelburg, J.J. and Melack, J. 2007. Plumbing the global carbon cycle: integrating inland waters into the terrestrial carbon budget. Ecosystems, 10:171-184.

Coloso JJ, Cole JJ, Pace L. 2011. Difficulty in discerning drivers of lake ecosystem metabolism with high-frequency data. Ecosystems, 14:935-948, doi:10.1007/s10021-011-9455-5

Dokulil, M., Bauer, K. and Silva, E. I. L. 1983. An assessment of the phytoplankton biomass and primary productivity of Parakrama Samudra, a shallow man-made lake in Sri Lanka. In: Schiemer, F. (ed.) Limnology of Parakrama Samudra - Sri Lanka: a Case Study of an Ancient Man-Made Lake in the Tropics. Developments in Hydrobiology 12: 49-77.

Duarte, C.M. and Prairie, Y.T., 2005. Prevalence of heterotrophy and atmospheric $\mathrm{CO}_{2}$ emissions from aquatic ecosystems. Ecosystems, 8(7), pp.862-870.

Downing, J. A. 2014. Limnology and oceanography: two estranged twins reuniting by global change. Inland Waters 4: 215-232.

Erikson, R., E. Hooker, M. Mejía, A. Zelaya \& Vammen, K. (1998). Optimal conditions for a primary production in a polymictic tropical lake (Lake Xolotlán, Nicaragua). Hydrobiologia, 382, 1-16.

Falkowski, P.G., Laws, E.A., Barber, R.T. and Murray, J.W., 2003. Phytoplankton and their role in primary, new, and export production. In Ocean biogeochemistry (pp. 99-121). Springer, Berlin, Heidelberg. 
630

631

632

633

634

635

636

637

638

639

640

641

642

643

644

645

646

647

648

649

650

651

652

653

654

655

656

657

658

659

660

661

662

663

664

665

666

667

668

Fontaine, T. D. and Ewel, K. C. 1981. Metabolism of a Florida lake ecosystem. Limnology and Oceanography, 26(4), 754-763.

Gazeau, F., Borges, A. V., Barron, C., Duarte, C. M., Iversen, N., Middelburg, J. J., Bruno Delille, Marie-Dominique Pizay, Michel Frankignoulle, Jean-Pierre Gattuso. 2005. Net ecosystem metabolism in a micro-tidal estuary (Randers Fjord, Denmark): evaluation of methods. Marine Ecology Progress Series, 301: 23-41.

Geraldes, A. M., and Boavida, M. J. (2005). Seasonal water level fluctuations: Implications for reservoir limnology and management. Lakes \& Reservoirs: Research \& Management, 10: 59-69.

Geider, R. J. and Osborne, B. A. 1989. Respiration and microalgal growth: a review of the quantitative relationship between dark respiration and growth. New Phytologist 112:327-341.

González, E. J., Ortaz, M., Peñaherrera, C., Montes, E., Matos, M. L. and Mendoza, J. 2003. Fitoplancton de cinco embalses de Venezuela con diferentes estados tróficos. Limnetica, 22(1-2), 15-35.

González, E. J., Ortaz, M., Peñaherrera, C. and Matos, M. L. 2004. Fitoplancton de un embalse tropical hipereutrófico (Pao-Cachinche, Venezuela): abundancia, biomasa y producción primaria. Interciencia, 29(10), 548-555.

Gupta, G.V.M., Sarma, V.V.S.S., Robin, R.S., Raman, A.V., Kumar, M.J., Rakesh, M. and Subramanian, B.R., 2008. Influence of net ecosystem metabolism in transferring riverine organic carbon to atmospheric CO 2 in a tropical coastal lagoon (Chilka Lake, India). Biogeochemistry, 87(3), pp.265285.

Hararuk, O., Zwart, J.A., Jones, S.E., Prairie, Y. and Solomon, C.T., 2018. Model-data fusion to test hypothesized drivers of lake carbon cycling reveals importance of physical controls. Journal of Geophysical Research: Biogeosciences. Published on line: 30 March 2018. https://doi.org/10.1002/2017JG004084

Hoellein, T.J., Bruesewitz, D.A. and Richardson, D.C., 2013. Revisiting Odum (1956): A synthesis of aquatic ecosystem metabolism. Limnology and Oceanography, 58(6), pp.2089-2100.

Jiménez-Contreras, J., Sarma, S. S. S., Merino-Ibarra,M., \& Nandini, S. (2009). Seasonal changes in the rotifer (Rotifera) diversity from a tropical high altitude reservoir (Valle de Bravo, Mexico). Journal of Environmental Biology, 30(2), 191-195.

Khondker, M. and Kabir, M. A. 1995. Phytoplankton primary production in a mesotrophic pond in subtropical Bangladesh. Hydrobiologia, 304(1), 39-47.

Kolding, J. and van Zwieten, P. 2012. Relative lake level fluctuations and their influence on productivity and resilience in tropical lakes and reservoirs. Fisheries Research 115-116: 99-109.

Kosten, S., Roland, F., Da Motta Marques, D.M., Van Nes, E.H., Mazzeo, N., Sternberg, L.D.S., Scheffer, M. and Cole, J.J., 2010. Climate-dependent CO2 emissions from lakes. Global Biogeochemical Cycles, 24(2):1-7.

$\mathrm{Ku}, \mathrm{H} .1966$. Notes on the use of propagation of error formulas. Journal of Research of the National Bureau of Standards C. Engineering and Instrumentation, 70, 263-273.

Lehrter, J. C. and Cebrian, J. 2010. Uncertainty propagation in an ecosystem nutrient budget. Ecological Applications, 20(2): 508-524. 
669

670

671

672

673

674

675

676

677

678

679

680

681

682

683

684

685

686

687

688

689

690

691

692

693

694

695

696

697

698

699

700

701

702

703

704

705

706

707

708

Lewis, W. 2011. Global primary production of lakes: 19th Baldi Memorial Lecture. Inland Waters, 1:128.

Lewis, Jr. W. M. (1974). Primary production in the plankton community of a tropical lake. Ecological Monographs, 377-409.

Liang, Y., Wang, J. and Hu, C. 1988. Hydrobiology of a flooding ecosystem, Lake Chenhu in Hanyang, Hubei, with preliminary estimation of its potential fishery production capacity. Chinese Journal of Oceanology and Limnology, 6, 1-14.

Lind, O., Doyle, R., Vodopich, D., Trotter, B., Limón, J. and Dávalos-Lind, L. 1992. Clay turbidity: governing of phytoplankton production in a large, nutrient-rich tropical lake (Lago de Chapala, México). Limnology and Oceanography, 37, 549-565.

Mac Donagh, M. E., Casco, M. A. and Claps, M. C. 2009. Plankton relationships under small water level fluctuations in a subtropical reservoir. Aquatic Ecology, 43, 371-381.

Melack, J. M. 1976. Primary Productivity and Fish Yields in Tropical Lakes. Transactions of the American Fisheries Society, 105:5, 575-580.

Melack, J. M. 1979. Temporal variability of phytoplankton in tropical lakes. Oecologia, 44(1), 1-7.

Merino-Ibarra, M., Monroy-Ríos, E., Vilaclara, G., Castillo, S., Gallegos, M.E. and Ramírez-Zierold, J. 2008. Physical and chemical limnology of a wind-swept tropical highland reservoir. Aquatic Ecology, 42: 335-345.

Mugidde, R., 1993. The increase in phytoplankton primary productivity and biomass in Lake Victoria (Uganda). Verhandlungen des Internationalen Verein Limnologie, 25: 846-849.

Nandini, S., Merino-Ibarra, M. and Sarma, S.S.S. 2008. Seasonal changes in the zooplankton abundances of the reservoir Valle de Bravo (State of Mexico, Mexico). Lake and Reservoir Management, 24:321330.

Natarajan, A. V. 1989. Environmental impact of Ganga Basin development on gene-pool and fisheries of the Ganga River system. In: D.P. Dodge (Ed.). Canadian special publication of fisheries and aquatic sciences (pp 545-560). Canada. DFO.

Odum, E.P. 1971. Fundamentals of ecology. W.B. Saunders, Philadelphia.

Olvera-Viascán, V., Bravo-Inclán, L. and Sánchez-Chávez, J. 1998. Aquatic ecology and management assessment in Valle de Bravo reservoir and its watershed. Aquatic Ecosystem Health and Management 1:277-290.

Oseguera, L. A., Alcocer, J., Quintero, V., and Einye, Y. 2015. Metabolismo lacustre de un lago tropical profundo:¿ Fuente o sumidero de carbono?. Hidrobiológica, 25(3), 391-399.

Ramírez-García, P., Nandini, S., Sarma, S., Robles, E., Cuesta, I. and Hurtado, D. 2002. Seasonal variations of zooplankton abundance in the freshwater reservoir Valle de Bravo. Hydrobiologia, 467:99-108.

Ramírez-Zierold, J., Merino-Ibarra, M., Monroy-Ríos, E., Olson, M., Castillo, F.S., Gallegos, M.E. and Vilaclara, G. 2010. Changing water, phosphorus and nitrogen budgets for Valle de Bravo reservoir, water supply for Mexico City Metropolitan Area. Lake and Reservoir Management, 26(1):23-34.

Ramírez-Zierold J. Merino-Ibarra M., Castillo-Sandoval F.S. Monroy-Ríos E., López-Gómez L.M., Quintanilla-Terminel J.G. Valdespino-Castillo P.M., Jiménez-Contreras J., Valeriano-Riveros M.E. y 
Vilaclara-Fatjó G. 2015. Variabilidad de la mezcla vertical y el flujo de nutrientes asociado en un embalse estratificado, Valle de Bravo, México. In: Alcocer, J., M. Merino-Ibarra, E. Escobar-Briones. (Ed). 2105. Tendencias de investigación en Limnología tropical: Perspectivas universitarias en Latinoamérica: (39-51). Asociación Mexicana de Limnología, A.C. e Instituto de Ciencias del Mar y Limnología, UNAM. México. ISBN 978-607-02-7199-1.

Räsänen, T.A., Varis, O., Scherer, L. and Kummu, M., 2018. Greenhouse gas emissions of hydropower in the Mekong River Basin. Environmental Research Letters, 13(3), p.034030.

Raymond, P.A., Hartmann, J., Lauerwald, R., Sobek, S., McDonald, C., Hoover, M., Butman, D., Striegl, R., Mayorga, E., Humborg, C. and Kortelainen, P., 2013. Global carbon dioxide emissions from inland waters. Nature, 503(7476), pp.355-359.

Reynolds CS. 1999. Non-determinism to probability, or N:P in the community ecology of phytoplankton: nutrient ratios. Arch Hydrobiol. 146(1):23-35.

Richerson, P. J., Neale, P. J., Wurtsbaugh, W., Alfaro, T. R. and Vincent, W. 1986. Patterns of temporal variation in Lake Titicaca. A high altitude tropical lake. I. Background, physical and chemical processes, and primary production. Hydrobiologia, 138(1), 205-220.

Sacristán Ramírez, Aratxa. 2017. "Water and phosphorous assesment in the Valle de Bravo reservoir during 2008-2010”. Earth Sc. Thesis, Universidad Nacional Autónoma de México.

Schelske, C. L., Aldridge, F. J., Carrick, H. J., and Coveney, M. F. 2003. Phytoplankton community photosynthesis and primary production in a hypereutrophic lake, Lake Apopka, Florida. Archiv für Hydrobiologie, 157(2), 145-172.

Schmidt, G. W. 1973. Primary production in the three types of Amazonian waters. III. Primary productivity of phytoplankton in a tropical flood plain lake of central Amazonia, Lago do Castanho, Amazonas, Brazil. Amazonia, 4:, 379-404.

Sarmento, H. 2012. New paradigms in tropical limnology: the importance of the microbial food web. Hydrobiologia 686:1-14.

Sobek, S., Tranvik, L.J., Prairie, Y.T., Kortelainen, P. and Cole, J.J., 2007. Patterns and regulation of dissolved organic carbon: An analysis of 7,500 widely distributed lakes. Limnology and Oceanography, 52(3), pp.1208-1219.

Solomon, C.T., Bruesewitz, D.A., Richardson, D.C., Rose, K.C., Van de Bogert, M.C., Hanson, P.C. and Zhu, G. 2013. Ecosystem respiration: Drivers of daily variability and background respiration in lakes around the globe. Limnology and Oceanography, 58(3): 849-866.

Staehr, P.A., Sand-Jensen, K., Raun, A. L., Nielsson, B. and Kidmose, J. 2010. Drivers of metabolism and net heterotrophy in contrasting lakes. Limnology and Oceanography. 55:817-830.

Staehr, P.A., Testa, J.M., Kemp, W.M., Cole, J., Sand-Jensen, K. and Smith, S.V. 2012. The metabolism of aquatic ecosystems: history, applications, and future challenges. Aquatic Sciences, 74:15-29.

Tranvik, L. J., Downing, J. A., Cotner, J. B., Loiselle, S. A., Striegl, R. G., Ballatore, T. J., Peter Dillon, Kerri Finlay, Kenneth Fortino, Lesley B. Knoll, Pirkko L. Kortelainen, Tiit Kutser, Soren Larsen, Isabelle Laurion, Dina M. Leech, S. Leigh McCallister, Diane M. McKnight,q John M. Melack, Erin Overholt,j Jason A. Porter, Yves Prairie, William H. Renwick, Fabio Roland, Bradford S. Sherman, David W. Schindler, Sebastian Sobek, Alain Tremblay, Michael J. Vanni, Antonie M. Verschoor, Eddie von Wachenfeldt, and Gesa A. Weyhenmeyer. 2009. 
750

751

752

753

754

755

756

757

758

759

760

761

762

763

764

765

766

767

768

769

770

Lakes and reservoirs as regulators of carbon cycling and climate. Limnology and Oceanography, 54: 2298-2314.

Valdespino-Castillo, P.M., Merino-Ibarra, M., Jiménez-Contreras, J., Castillo-Sandoval, F.S., RamírezZierold, J.A. 2014. Community metabolism in a deep (stratified) tropical reservoir during a period of high water-level fluctuations. Environmental Monitoring and Assessment, 186 (10): 6505-6520.

Valdespino-Castillo, P.M., Merino-Ibarra, M., Ramírez-Zierold, J.A., Castillo-Sandoval, F.S. y González de Zayas,, R., Carnero-Bravo, V. 2018. Towards the construction of a carbon fluxes inventory of tropical lakes: a unifying method pipeline. Tecnología y Ciencias del Agua (in press).

Valeriano-Riveros, M.E., Vilaclara, G., Castillo-Sandoval, S., Merino-Ibarra, M. 2014. Phytoplankton composition changes under water-level fluctuations in a high-altitude, tropical reservoir. Inland Waters, 4: 337-348.

Vareschi, E. 1982. The ecology of Lake Nakuru (Kenya). III. Abiotic factors and primary production. Oecologia, 81-101.

Vijayaraghavan, S. 1971. Seasonal variation in primary productivity in three tropical ponds. Hydrobiologia, 38(3-4), 395-408.

Wantzen, K. M., Rothhaupt, K.-O., Mortl, M., Cantonati, M., Tóth, L., and Fischer, P. 2008. Ecological effects of water level fluctuations in lakes: an urgent issue. Hydrobiologia, 613, 1-4.

Wetzel, R. G. and G. E. Likens. 1991. Limnological Analyses. W. B. Saunders. NY, USA. 391 p.

Zohary, T. and Ostrovsky, I. 2011. Ecological impacts of excessive water level fluctuations in stratified freshwater lakes. Inland Waters, 1: 47-59. 
Figure 1

Water level fluctuations (meters below capacity) in the Valle de Bravo reservoir from 2006 to 2015

Blue dotted boxes indicate the circulation periods.

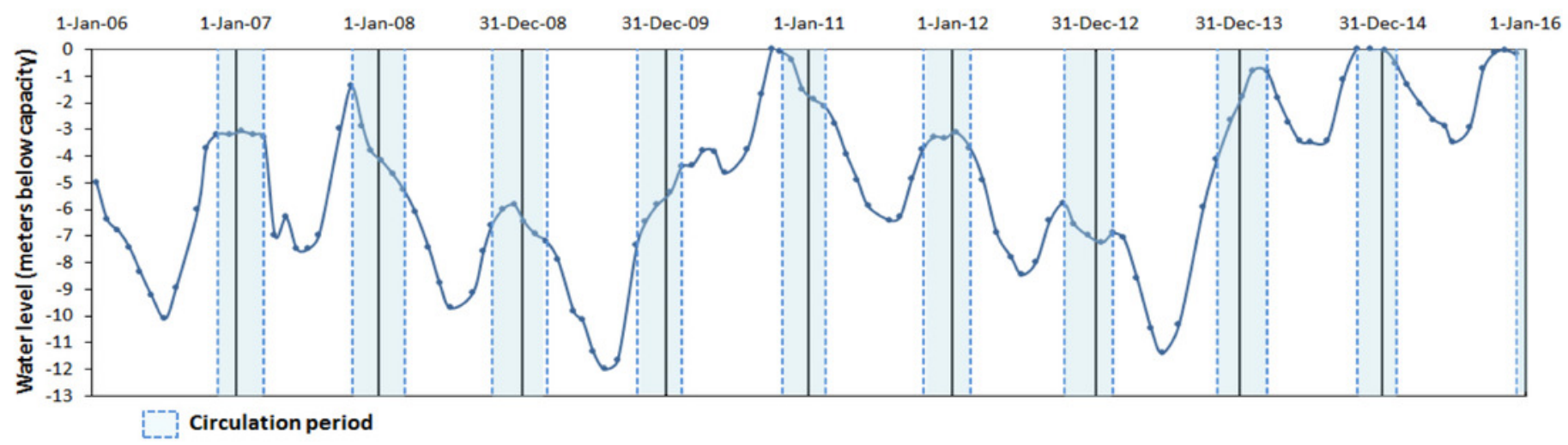


Figure 2

Vertical and temporal variation of temperature $\left({ }^{\circ} \mathrm{C}\right)$ in Valle de Bravo reservoir from 2007 to 2015.

Brown shade indicates the bottom below the reservoir.

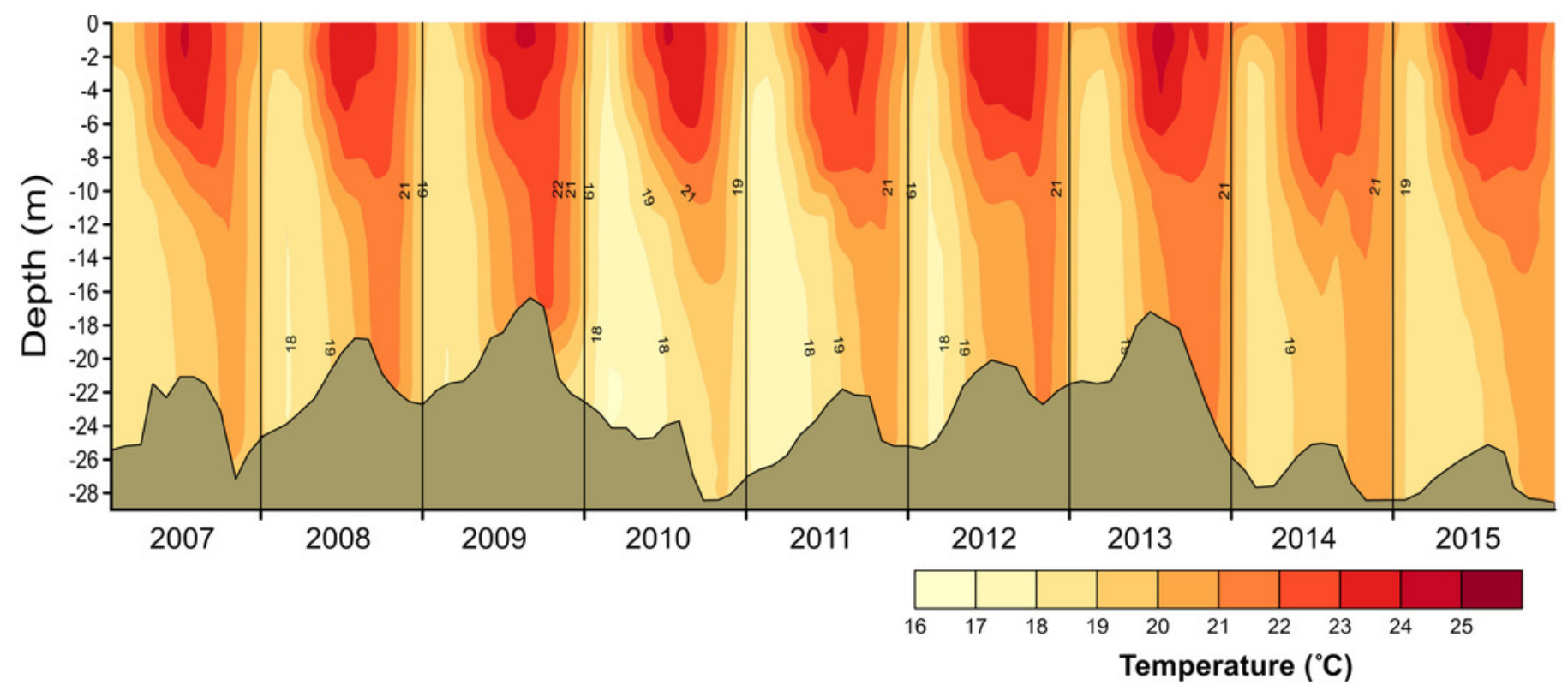




\section{Figure 3}

Vertical and temporal variation of dissolved oxygen (DO, $\mathrm{mg} \mathrm{L}^{-1}$ ) in Valle de Bravo reservoir from 2007 to 2015.

The red line represents depth of the production layer $\left(Z_{p}\right)$ and the black line the depth of the mixed layer $\left(Z_{\text {mix }}\right)$, identified by the $1 \mathrm{mg} \mathrm{L}^{-1}$ oxygen isoline. Brown shade indicates the bottom below the reservoir.

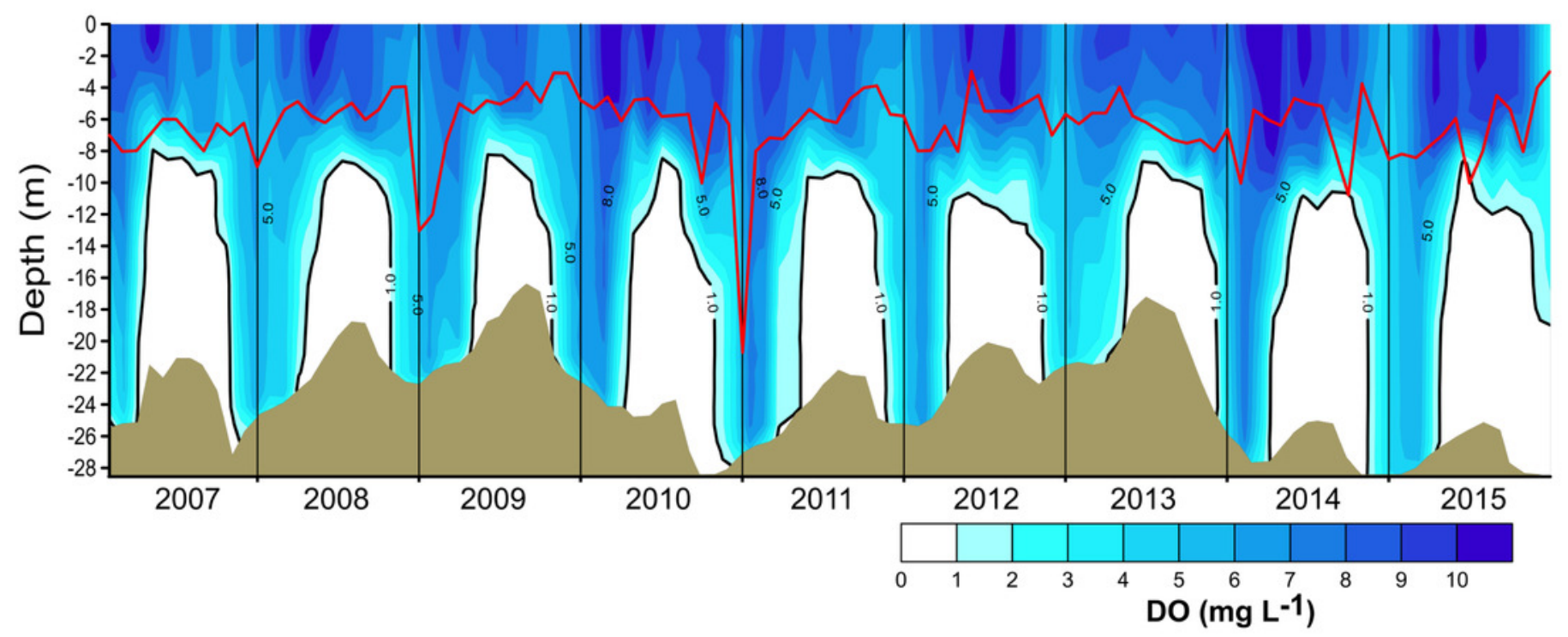




\section{Figure 4}

Vertical variations of the metabolic rates along the annual cycle within the production layer in Valle de Bravo reservoir: (a) gross primary production (GPP); (b) respiration $\left(R_{p l}\right)$ and (c) net primary production (NPP).

The figure was constructed with the monthly averages of the data gathered from 2007 to 2015. Letters in the time axis indicate the months (i.e. J=January, F=February, and so on.) 

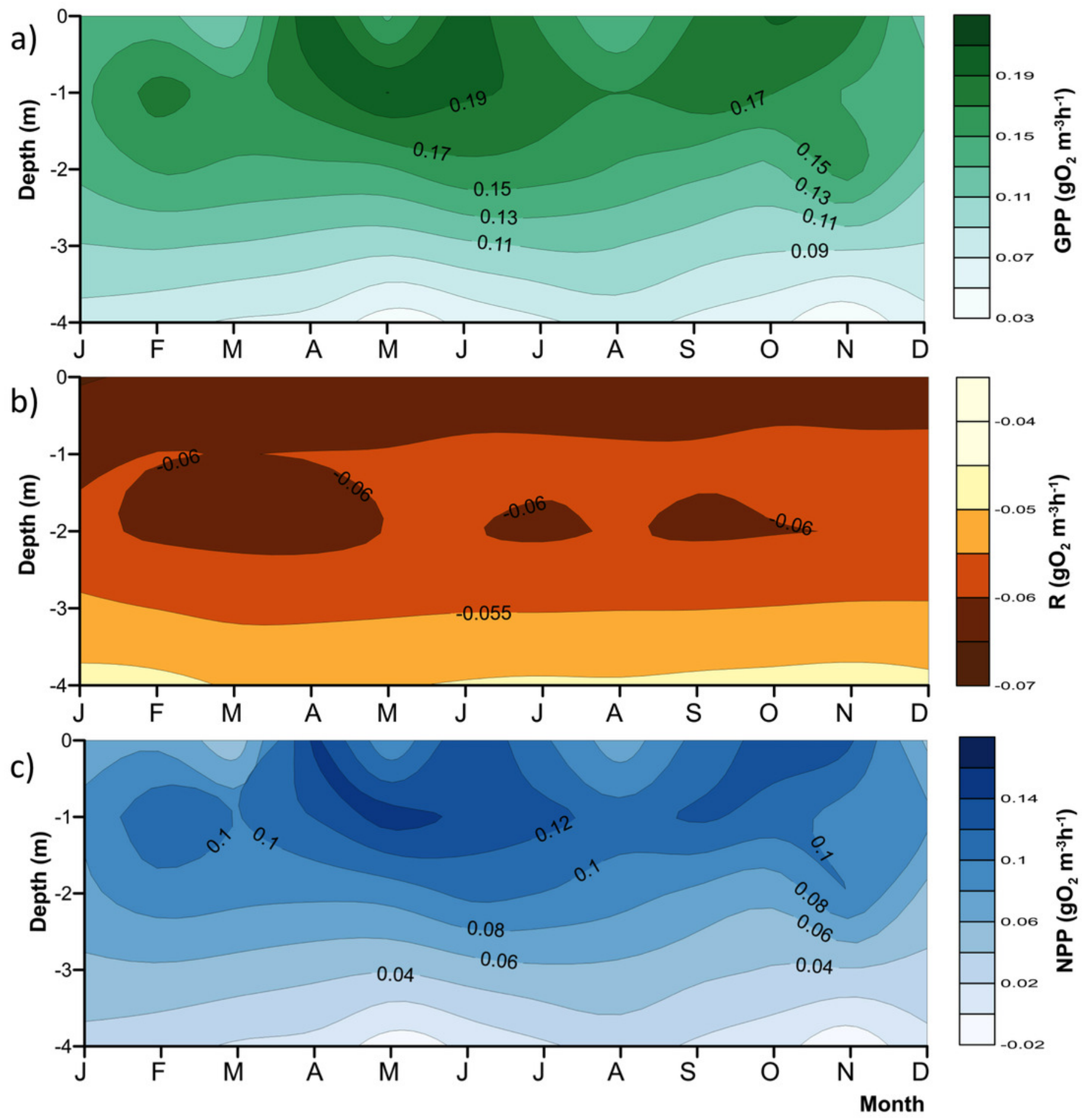
Figure 5

Temporal variations of: (a) gross primary production (GPP), respiration $\left(R_{p}\right)$ and net primary production (NPP) in the production layer and (b) Aerobic respiration below the production layer $\left(A R_{\text {bp }}\right)$ in Valle de Bravo reservoir from 2007

Error bars indicate the confidence intervals $(\mathrm{Cl})$ calculated from the propagated SE and $d f$ at $\alpha=95 \%$. Blue dotted boxes indicate the circulation periods.
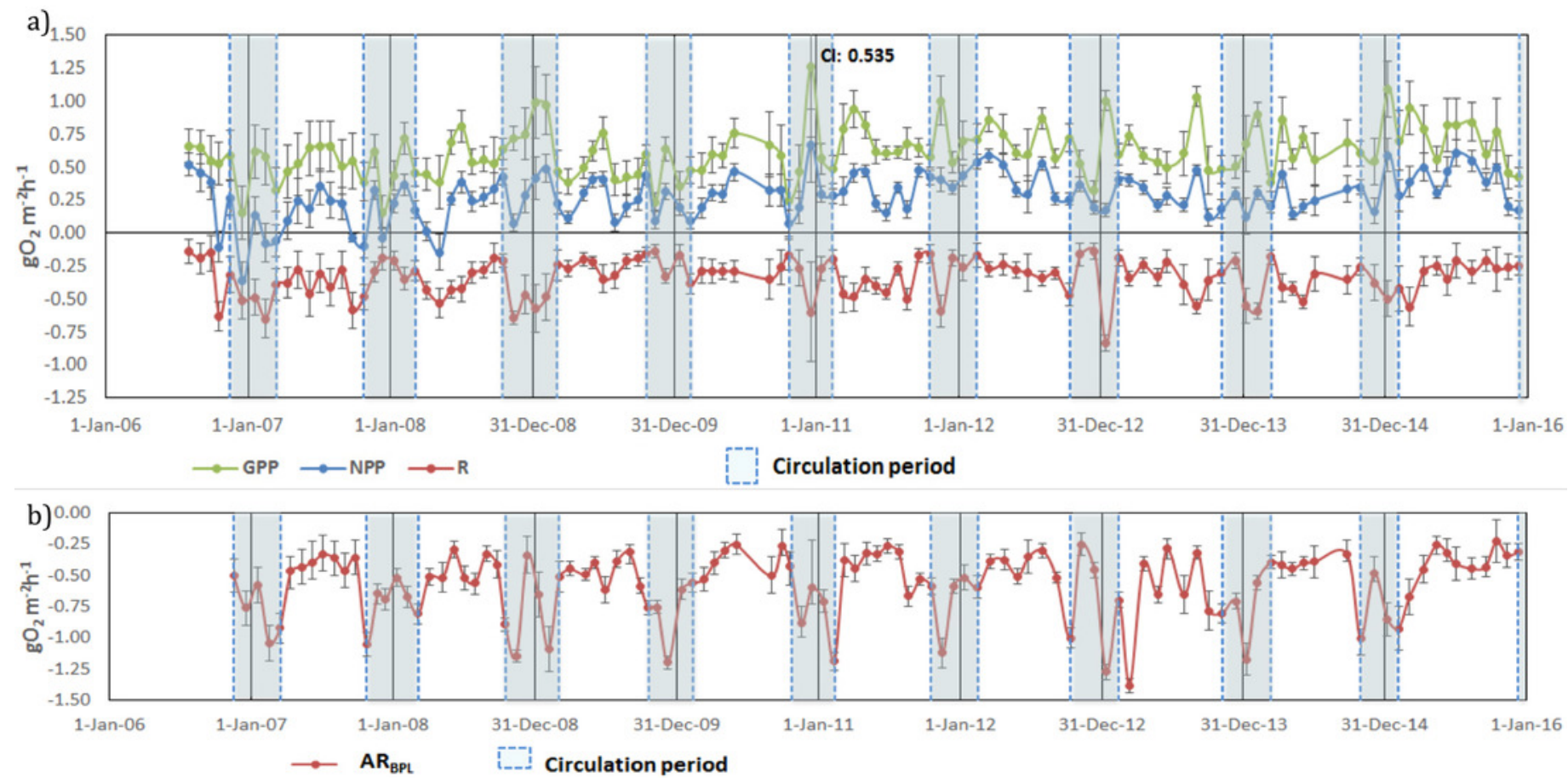
Figure 6

Ecosystem Metabolic Balance (GPP: $\mathrm{R}_{\text {Total }}$ quotient in carbon units) for the Valle de Bravo reservoir from November 2007 to December 2015.

Blue dotted boxes indicate the circulation periods.

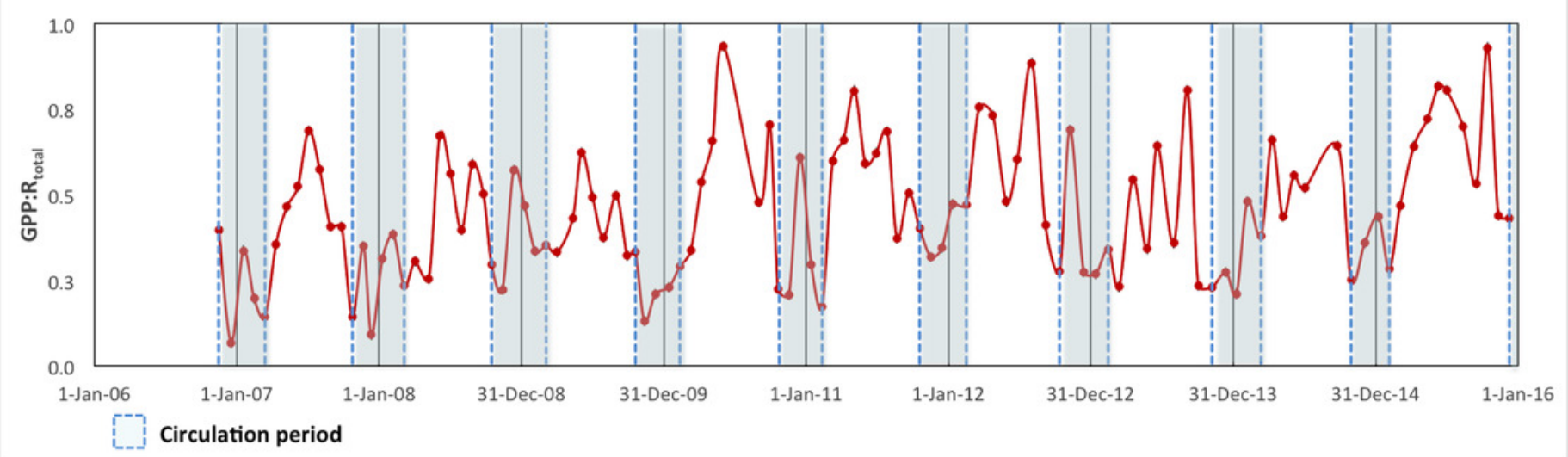




\section{Figure 7}

Schematic representation of the functional water layers, the main processes and relations occurring in Valle de Bravo in the stratification and circulation periods during 2006-2015.

All abbreviations as specified in the text. Green shade depicts the production layer. Light blue shade depicts the aphotic layer. Darker blue shade depicts the anoxic layer. Brown shade indicates the bottom below the reservoir.

a) Stratification

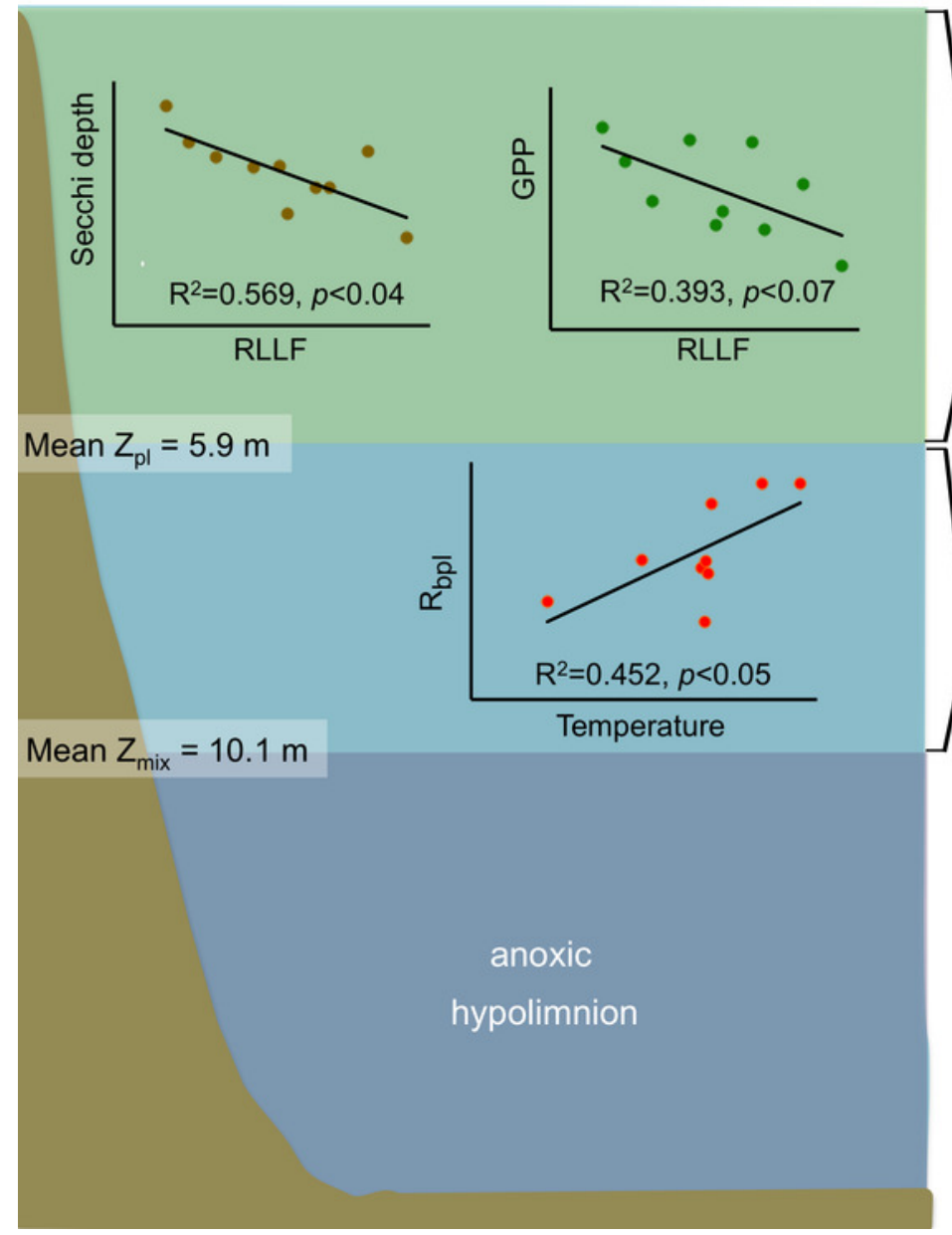

b) Circulation
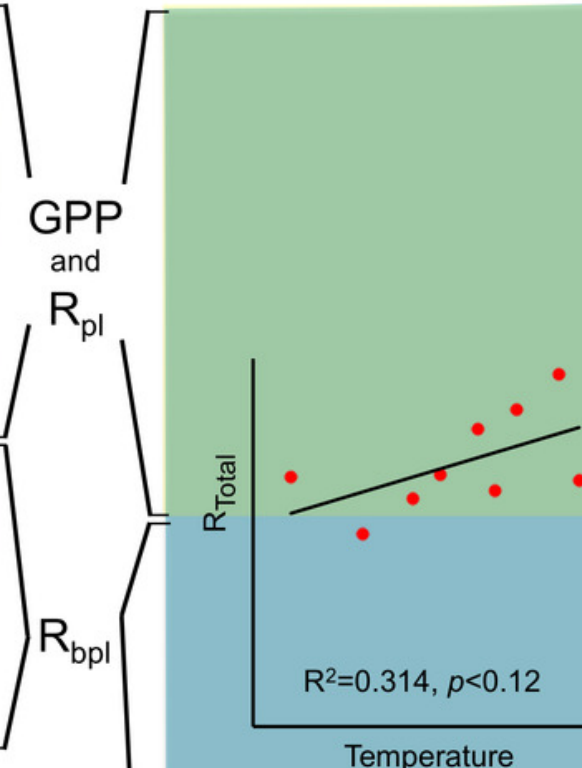

Mean $Z_{p l}=6.8 m$

$\mathrm{R}^{2}=0.314, p<0.12$

Temperature 


\section{Table $\mathbf{1}$ (on next page)}

Environmental drivers and chlorophyll-a in Valle de Bravo reservoir; averages during the stratification (S), circulation (C) and annually (A) for the 2006-2015 period

RLLF $=$ mean lake level amplitude/mean depth $* 100$ after Kolding and van Zwieten (2012). 


\begin{tabular}{|c|c|c|c|c|c|c|c|c|c|c|c|c|c|c|}
\hline \multirow[t]{2}{*}{ Year } & \multicolumn{2}{|r|}{ Period } & \multicolumn{3}{|c|}{ Temperature $\left({ }^{\circ} \mathrm{C}\right)$} & \multicolumn{3}{|c|}{ Secchi depth (m) } & \multicolumn{3}{|c|}{$\begin{array}{c}\text { Chlorophyll-a } \\
\left(\mu \mathrm{g} \mathrm{L}^{-1}\right)\end{array}$} & \multicolumn{3}{|c|}{ RLLF } \\
\hline & $\mathbf{S}$ & $\mathbf{C}$ & $\mathbf{S}$ & $\mathbf{C}$ & $\mathbf{A}$ & $\mathbf{S}$ & $\mathbf{C}$ & $\mathbf{A}$ & $\mathbf{S}$ & C & A & $\mathbf{S}$ & $\mathbf{C}$ & $\mathbf{A}$ \\
\hline 2006 & Aug-Sep & Oct 2006-Mar 2007 & 21.85 & 19.62 & 21.22 & 1.24 & 1.60 & 1.42 & 15.3 & 12.0 & 13.0 & 29.5 & 15.1 & 30.9 \\
\hline 2007 & Apr-Sep & Oct 2007-Mar2 008 & 21.16 & 19.32 & 20.35 & 1.44 & 2.38 & 1.91 & 13.1 & 16.3 & 13.0 & 28.2 & 16.1 & 22.1 \\
\hline 2008 & Apr-Sep & Oct 2008-Mar 2009 & 21.23 & 19.98 & 20.47 & 1.39 & 2.44 & 1.91 & 8.4 & 13.2 & 11.5 & 36.6 & 30.9 & 32.2 \\
\hline 2009 & Apr-Sep & Oct 2009-Feb 2010 & 21.87 & 19.69 & 20.90 & 1.15 & 1.88 & 1.51 & 21.5 & 15.0 & 19.1 & 49.7 & 28.0 & 40.8 \\
\hline 2010 & Mar-Sep & Oct 2010-Feb 2011 & 20.05 & 18.77 & 19.47 & 1.31 & 2.52 & 1.91 & 10.3 & 3.5 & 8.9 & 17.5 & 5.7 & 13.4 \\
\hline 2011 & Mar-Oct & Nov 2011-Feb 2012 & 20.73 & 19.10 & 20.14 & 1.38 & 1.90 & 1.64 & 9.0 & 7.0 & 8.1 & 23.8 & 16.3 & 19.6 \\
\hline 2012 & Mar-Sep & Oct 2012-Mar 2013 & 21.19 & 19.45 & 20.51 & 1.37 & 2.01 & 1.69 & 15.1 & 13.8 & 13.0 & 34.3 & 31.8 & 30.4 \\
\hline 2013 & Apr-Oct & Nov 2013-Mar 2014 & 21.59 & 20.07 & 20.73 & 1.51 & 2.00 & 1.76 & 8.1 & 9.5 & 10.0 & 43.2 & 9.7 & 37.1 \\
\hline 2014 & Apr-Sep & Oct 2014-Feb 2015 & 21.21 & 19.79 & 20.48 & 1.56 & 2.44 & 2.00 & 8.3 & 6.4 & 8.8 & 12.7 & 0.6 & 7.7 \\
\hline 2015 & Mar-Nov & - & 21.18 & - & 20.74 & 1.65 & - & 1.65 & 12.4 & - & 10.4 & 8.9 & - & 6.8 \\
\hline Mean & & & 21.21 & 19.53 & 20.50 & 1.40 & 2.13 & 1.74 & 12.2 & 10.7 & 11.6 & 28.4 & 17.1 & 20.5 \\
\hline
\end{tabular}




\section{Table 2 (on next page)}

Mean daily metabolic carbon rates $\left(\mathrm{g} \mathrm{C} \mathrm{m}^{-2} \mathrm{~d}^{-1}\right)$ for the production layer and the full ecosystem of VB reservoir during the stratification (S), circulation (C) and annually $(A)$ for the 2006-2015 period

GPP, gross primary production; $\mathrm{R}_{\mathrm{pl}}$, Respiration in the production layer; NPP, net primary production; $\mathrm{R}_{\text {Total }}$ Aerobic Respiration in the full water column; Net Metabolism calculated as $\mathrm{GPP}+\mathrm{R}_{\text {Total }}$. Positive fluxes imply $\mathrm{CO}_{2}$ assimilation into biomass and negative ones its liberation to the water column. 
Production Layer

\begin{tabular}{|c|c|c|c|c|c|c|c|c|c|c|c|c|c|c|c|}
\hline \multirow{2}{*}{ Year } & \multicolumn{3}{|c|}{ GPP } & \multicolumn{3}{|c|}{ Rpl } & \multicolumn{3}{|c|}{ NPP } & \multicolumn{4}{|c|}{$\mathbf{R}_{\text {Total }}{ }^{3}$} & \multicolumn{2}{|c|}{$\begin{array}{c}\text { Net } \\
\text { Metabolism }\end{array}$} \\
\hline & $\mathbf{S}$ & $\mathrm{C}$ & $\mathbf{A}$ & $\mathbf{S}$ & $\mathrm{C}$ & $\mathbf{A}$ & $\mathbf{S}$ & $\mathbf{C}$ & $\mathbf{A}$ & $\mathbf{S}$ & $\mathrm{C}$ & $\mathbf{A}$ & $\mathbf{S}$ & $\mathrm{C}$ & $\mathbf{A}$ \\
\hline 2006 & 3.57 & 2.46 & 3.04 & -1.63 & -2.56 & -1.82 & 1.94 & -0.10 & 1.22 & - & -9.05 & - & - & -6.59 & - \\
\hline 2007 & 3.54 & 2.55 & 3.04 & -2.37 & -1.66 & -2.33 & 1.17 & 0.88 & 0.71 & -5.67 & -8.09 & -7.38 & -2.12 & -5.55 & -4.34 \\
\hline 2008 & 3.54 & 4.40 & 3.47 & -2.31 & -2.56 & -2.15 & 1.22 & 1.84 & 1.31 & -6.05 & -9.79 & -7.12 & -2.51 & -5.38 & -3.66 \\
\hline 2009 & 3.16 & 2.51 & 3.35 & -1.58 & -1.27 & -1.65 & 1.59 & 1.23 & 1.69 & -5.60 & -8.20 & -7.22 & -2.43 & -5.70 & -3.87 \\
\hline 2010 & 3.73 & 3.23 & 3.40 & -1.78 & -1.61 & -1.74 & 1.95 & 1.62 & 1.65 & -5.00 & -8.39 & -5.97 & -1.27 & -5.16 & -2.57 \\
\hline 2011 & 4.40 & 3.83 & 4.03 & -2.38 & -1.48 & -2.05 & 2.02 & 2.34 & 1.98 & -5.78 & -7.62 & -7.03 & -1.38 & -3.79 & -3.01 \\
\hline 2012 & 4.32 & 3.45 & 3.84 & -1.77 & -1.93 & -1.56 & 2.56 & 1.51 & 2.28 & -5.31 & -8.42 & -5.79 & -0.99 & -4.97 & -1.95 \\
\hline 2013 & 3.86 & 3.20 & 3.72 & -2.09 & -1.99 & -2.07 & 1.77 & 1.22 & 1.64 & -7.65 & -8.35 & -8.40 & -3.79 & -5.15 & -4.69 \\
\hline 2014 & 4.21 & 3.98 & 3.81 & -2.50 & -2.10 & -2.32 & 1.70 & 1.89 & 1.49 & -5.78 & -9.31 & -7.10 & -1.57 & -5.33 & -3.29 \\
\hline 2015 & 4.42 & - & 4.31 & -1.79 & - & -1.87 & 2.63 & - & 2.44 & -5.24 & - & -5.99 & -0.82 & - & -1.68 \\
\hline Mean & 3.88 & 3.29 & 3.60 & -2.06 & -1.83 & -1.97 & 1.86 & 1.38 & 1.64 & -5.79 & -8.58 & -6.89 & -1.91 & -5.29 & -3.29 \\
\hline
\end{tabular}

Full Ecosystem 


\section{Table 3(on next page)}

Fraction of the production ( $f$ - ratio) that can potentially be exported from the production layer of Valle de Bravo reservoir during the stratification (S), circulation (C) and annually (A) for the 2006-2015 period. 
1

\begin{tabular}{cccccc}
\hline \multirow{2}{*}{$\begin{array}{c}\text { Ye } \\
\text { ar }\end{array}$} & \multicolumn{2}{c}{ Period } & \multicolumn{3}{c}{ f-ratio } \\
\cline { 2 - 6 } 200 & Aug-Sep & Oct 2006-Mar 2007 & 0.54 & -0.04 & 0.40 \\
200 & Apr-Sep & Oct 2007-Mar2 008 & 0.33 & 0.35 & 0.23 \\
200 & Apr-Sep & Oct 2008-Mar 2009 & 0.35 & 0.42 & 0.38 \\
200 & Apr-Sep & Oct 2009-Feb 2010 & 0.50 & 0.49 & 0.51 \\
201 & Mar-Sep & Oct 2010-Feb 2011 & 0.52 & 0.50 & 0.49 \\
201 & Mar-Oct & Nov 2011-Feb 2012 & 0.46 & 0.61 & 0.49 \\
201 & Mar-Sep & Oct 2012-Mar 2013 & 0.59 & 0.44 & 0.59 \\
201 & Apr-Oct & Nov 2013-Mar 2014 & 0.46 & 0.38 & 0.44 \\
201 & Apr-Sep & Oct 2014-Feb 2015 & 0.40 & 0.47 & 0.39 \\
201 & Mar-Nov & - & 0.60 & - & 0.57 \\
\hline Me & & & $\mathbf{0 . 4 8}$ & $\mathbf{0 . 4 0}$ & $\mathbf{0 . 4 5}$
\end{tabular}

$2{ }^{1}$ Sampling began in August 


\section{Table 4 (on next page)}

Metabolism data compiled for previous studies in tropical aquatic systems

GPP, gross primary production; R, Respiration; NPP, net primary production; all rates in carbon units $\left(\mathrm{g} \mathrm{C} \mathrm{m}^{-2} \mathrm{~d}^{-1}\right)$. Systems are ordered by mean value of GPP. Zpl, depth of the production layer. Dash ( - ) indicates when the number of sampled levels, or the depth of the production layer, where not specified by the authors. Means and P:R were calculated from the original data when not reported and converted from $\mathrm{O}_{2}$ to $\mathrm{C}$ units when necessary. 


\begin{tabular}{|c|c|c|c|c|c|c|c|c|c|c|c|}
\hline \multirow[t]{2}{*}{ Trophic state } & \multirow[t]{2}{*}{ System } & \multicolumn{2}{|c|}{ GPP } & \multicolumn{2}{|c|}{$\mathbf{R}$} & \multicolumn{2}{|c|}{ NPP } & \multirow[t]{2}{*}{$\mathbf{P}: \mathbf{R}$} & \multirow{2}{*}{$\begin{array}{c}\text { Number } \\
\text { of } \\
\text { depths } \\
\text { sampled }\end{array}$} & \multirow{2}{*}{$\begin{array}{l}\text { Zpl } \\
(\mathrm{m})\end{array}$} & \multirow[t]{2}{*}{ Reference } \\
\hline & & Mean & Range & Mean & Range & Mean & Range & & & & \\
\hline Oligo- & Chapala, Mexico & 0.3 & & & & & & & 3 & - & Lind et al. 1992 \\
\hline \multirow[t]{3}{*}{ mesotrophic } & Baringo, Kenya & 0.8 & & & & & & & - & - & Melack 1976 \\
\hline & Rio Ganjes, India & 1.0 & $0.9-1.0$ & & & & & & - & - & Natarajan 1989 \\
\hline & Titicaca, Peru-Bolivia & 1.1 & & & & & & & 9 & - & Richerson et al. 1986 \\
\hline \multirow[t]{12}{*}{ Eutrophic } & Chad, Chad & 1.3 & & & & & & & - & - & Melack 1976 \\
\hline & Castanho, Amazona, Brazil & 1.4 & & & & & & & - & - & Schmidt 1973 \\
\hline & La Mariposa, Venezuela & 1.8 & $0.9-2.6$ & & & & & & - & - & González et al. 2003 \\
\hline & Naivasha, Kenya & 1.9 & $1.5-2.3$ & & & & & & - & - & Melack 1979 \\
\hline & Crescent I. Crater, Kenya & 2.1 & $1.1-3.1$ & & & & & & - & - & Melack 1979 \\
\hline & Chang Jiang, Yangtze, China & 2.4 & $1.1-3.6$ & & & & & & - & - & Liang et al. 1988 \\
\hline & Apopka, United States & 2.5 & & & & 1.1 & $1.0-2.0$ & & 1 & 1.1 & Schelske et al. 2003 \\
\hline & Lago Lanao, Filipinas & 2.6 & & & & 1.7 & & & 13 & 15.0 & Lewis 1974 \\
\hline & Nakuru, Kenya & 2.6 & $0.3-4.9$ & & & & & & 12 & - & Vareschi 1982 \\
\hline & Quebrada Seca, Venezuela & 2.7 & $1.8-3.5$ & & & & & & - & - & González et al. 2003 \\
\hline & Alchichica, Mexico & 2.9 & & 2.0 & & 0.8 & & 1.45 & - & - & Oseguera et al. 2015 \\
\hline & Victoria, Gulf, Uganda & 3.0 & & & & & & & - & - & Melack 1976 \\
\hline \multirow[t]{2}{*}{ Hypertrophic } & Oloiden, Kenya & 3.1 & $1.6-4.5$ & & & & & & - & - & Allanson 1990 \\
\hline & Kainji, Nigeria & 3.2 & & & & & & & - & - & Melack 1976 \\
\hline
\end{tabular}


Poza Yanamalai, India

Tissawewa reservoir, Sri Lanka

Volta, Ghana

Conway, United States

Albert, East Africa

Valle de Bravo, Mexico

Victoria offshore, Uganda

Tanganyika

Mcllwaine, Zimbabwe

Pao Canchinche, Venezuela

Parakkrama Samudra, Sri Lanka

Shahidullah Hall, Bangladesh

Bosomtwe, Ghana

ES Seridó reservoir, Brazil

Estanque Teppakulam, India

George, Uganda

Victoria offshore, Uganda

Poza Othakadai, India

Lago Xolotlán, Nicaragua

Victoria, Pilkington, Uganda
3.2

3.3

$$
3.4
$$

3.6

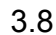

3.9

4.1

4.2

4.7

4.9

5.0

$2.0-8.0$

5.4

6.8

$8.7 \quad 1.5-15.8$

$9.0 \quad 6.0-12.0$

10.9

$1.0-5.4$

$2.6-4.0$

$0.8-6.0$

$1.6-6.0$

$1.0-6.8$
2.8

$0.3-$ 5.2

3.7

4.3

5.2
2.2

$0.5-3.9 \quad 1.42$

0.4

$-0.3$

$0.9-1.2 \quad 1.55$

$-0.4$

$-3.29$

$0.5-3.9$

0.52

0.89

1.15
1.10
0.94

1.15

0.94
$1 \quad-\quad$ Vijayaraghavan 1971

4

1.5 Amarasinghe and Vijverberg 2002

- $\quad$ Melack 1976

- $\quad$ Fontaine and Ewel 1981

- $\quad$ Melack 1976

6.4 This study

- $\quad$ Melack 1976

Melack 1976

- $\quad$ Allanson 1990

2.2 González et al. 2004

2.1 Dokulil et al. 1983

- $\quad$ Khondker and Kabir 1995

- $\quad$ Awortwi 2010

- $\quad$ Almeida et al. 2016

- $\quad$ Vijayaraghavan 1971

- $\quad$ Melack 1976

13.5 Mugidde 1993

- Vijayaraghavan 1971

$8 \quad$ Erikson et al. 1998

5.0 Mugidde 1993 